\title{
Native Prussian carp (Carassius gibelio) health status, biochemical and histological responses to treated wastewaters ${ }^{\wedge}$
}

\author{
Natalija Topić Popović ${ }^{\mathrm{a}, *}$, Ivančica Strunjak-Perović ${ }^{\mathrm{a}}$, Josip Barišić ${ }^{\mathrm{a}}$, Slavko Kepec ${ }^{\mathrm{b}}$, Margita Jadan ${ }^{\mathrm{a}}$, \\ Blanka Beer-Ljubićc $^{c}$, Vesna Matijatko ${ }^{c}$, Dušan Palić ${ }^{d}$, Goran Klobučar ${ }^{\mathrm{e}}$, Sanja Babića ${ }^{\mathrm{a}}$, Jasenka Gajdoš Kljusurić ${ }^{\mathrm{f}}$, \\ Rozelindra Čož-Rakovac ${ }^{\text {a }}$ \\ a Laboratory for Biotechnology in Aquaculture, Ruđer Bošković Institute, Bijenička 54, Zagreb, Croatia \\ b Virkom d.o.o, Public Water Supply and Wastewater Services, Kralja Petra Krešimira IV 30, Virovitica, Croatia \\ ${ }^{\mathrm{c}}$ Faculty of Veterinary Medicine, University of Zagreb, Heinzelova 55, Zagreb, Croatia \\ ${ }^{d}$ Chair for Fish Diseases and Fisheries Biology, Faculty of Veterinary Medicine, Ludwig-Maximilians University Munich, Germany \\ e Division of Zoology, Department of Biology, Faculty of Science, University of Zagreb, Rooseveltov trg 6, Zagreb, Croatia \\ ${ }^{\mathrm{f}}$ Faculty of Food Technology and Biotechnology, University of Zagreb, Pierottijeva 6, Zagreb, Croatia
}

\section{A R T I C L E I N F O}

Article history:

Received 25 February 2016

Received in revised form 19 July 2016

Accepted 28 July 2016

Available online $\mathrm{xxx}$

Keywords:

Prussian carp

Effluent

Plasma biochemistry

Histopathology

\section{A B S T R A C T}

The aim of this study was to assess the impact of treated wastewaters on native wild Prussian carp inhabiting effluent-receiving waters (ERC) receiving municipal and sugar plant treated wastewaters, further downstream waters (DW), and a detached canal unaffected by the WWTP activities. To that end, general fish health status was determined, including plasma biochemical, haematological, oxidative stress and tissue histopathological indices, over three seasons. The greatest tissue alterations were in fall in ERC during sugar beet processing, as hypertrophy of gill epithelial and interlamellar cells, necrosis and lymphocytic infiltration, hyperplasia and hypertrophy of renal tubules, distention of hepatic sinusoids. In fall the lowest leukocytes, lymphocytes and granulocytes $(2467 \pm 565,1333 \pm 264,1133 \pm 488$ cells $/ \mu \mathrm{L}$ respectively), as well as highest plasma ALP $(52.7 \pm 19.39 \mathrm{U} / \mathrm{L})$ were measured. ERC in fall had the highest ammonium $(20 \mathrm{mg} / \mathrm{L})$, nitrite $(1.48 \mathrm{mg} / \mathrm{L})$, nitrate $(13.4 \mathrm{mg} / \mathrm{L})$, and lowest dissolved $\mathrm{O}_{2}(1.23 \mathrm{mg} / \mathrm{L})$. Gill, kidney and liver alterations, and the highest plasma cholesterol $(9.1 \pm 1.98 \mathrm{mmol} / \mathrm{L})$ were noted in DW fish in fall. Tissue morphology during sugar cane processing seems a consequence of cellular and structural tissue integrity loss. Structural heterogeneity of gills and spleen was enhanced with increasing concentrations of heavy metals and correlated with oxidative stress (SOD $392.5 \pm 77.28 \mathrm{U} /$ L). Monogenean infestation was moderate in ERC fish in all seasons compared with DW fish. Prussian carp biological responses to multiple stressors, measured by the effects of WWTP on blood and tissue parameters, reached far downstream and were not of localized nature. This study demonstrated that in aquatic environments impacted with complex contaminants acting synergistically, causal relationships between biological responses and environmental stressors should be interpreted. Integrated histopathological, haematological and biochemical findings are valuable biomarkers for native fish adaptive patterns and monitoring of water quality/pollution of freshwater ecosystems.

Fish biological responses to multiple stressors of treated wastewaters were pronounced in specimens captured from both effluent and downstream waters.

CC 2016 Published by Elsevier Ltd.

\section{Introduction}

Many complex freshwater pollutants may be found in treated wastewaters and exert their effects on aquatic ecosystems and aquatic biota. Fish rapidly accumulate some toxic substances and respond to low concentrations of environmental pollutants (Radić et al., 2013). Fish are thus frequently used model systems in assessing these effects as they impact important physiological functions and thereby the overall health status. The biological effects may affect all levels of biological organization, and it is thus a challenge to identify adequate

\footnotetext{
* This paper has been recommended for acceptance by von Hippel Frank A.

* Corresponding author.

Email address: ntopic@irb.hr (N. Topić Popović)
}

biomarker indicators of toxic effects, especially since the treated wastewater effluents are chemically complex, constantly changing and biologically active. The inclusion of biomarkers as functional measures of exposure to stressors in field surveys of contaminated sites is increasingly being reported (Bernet et al., 2000, 2001; Owen et al., 2008; Kaur and Dua, 2014). It has been suggested that examination of haematological indices, plasma chemistry and oxidative stress could serve as a valuable diagnostic tool in assessing fish health impairment (Stoskopf, 1993), while their aberrations from standard values might be reflected in the histopathological tissue lesions (Bernet et al., 2001).

Prussian carp (Carassius gibelio) is widely distributed in Europe and Asia and commonly stocked together with carp (Cyprinus carpio). It inhabits still water bodies and lowland rivers, can tolerate pollution and low oxygen concentrations. It invaded European ponds, 
eutrophic lakes, canals, and small water reservoirs (USFWS, 2012). Prussian carp grows and reproduces rapidly, and competes with native fish for food and space. Juveniles frequently occur in complex habitats like reed belts. Presently it is the most dominant fish species in lentic and slowly running aquatic habitats (Lusk et al., 2010). Cyprinid fish, particularly carp, have often been included in studies where they were cage held/exposed in situ in municipal wastewater treatment plant (WWTP) effluents or in rivers receiving municipal WWTP effluents, while less is known of the biological effects on native wild carp captured from riverine sites influenced by the WWTP treated wastewater (Snyder et al., 2004; Huang et al., 2007; Barber et al., 2011; Karadag et al., 2014). In cage exposure studies, fish are held in conditions with restrained movement possibilities, they are often unable to feed adequately for their species requirements, and are generally unable to exert their characteristic behavioral patterns, and thus frequently die of stressful holding conditions (Snyder et al., 2004). Water management activities alter environmental characteristics of water bodies, often creating environmental traps for wild fish, which increase the risk for fish health (Hale et al., 2015). Although wild fish avoid deleterious polluted conditions and move to more favorable locations in order to enhance their survival and well being (Larrick et al., 1978), assessment of biological responses of wild-caught fish in WWTP-related waters will more likely indicate actual ecological effects of treated wastewater. It is of increasing importance to define appropriate indicators of anthropogenic disturbances for monitoring purposes. For example, Index of Biotic Integrity (IBI) has been extensively used in freshwater ecosystems (Jameson et al., 2001; Adams, 2002), and one of major IBI components in freshwater fish is the health status of fish populations, evaluated through presence and abundance of lesions, tumors and other apparently pathological conditions on fish (Adams and Greeley, 1999). In addition to macroscopic lesions, fish health status is also assessed using simple and rapid techniques such as evaluation of blood smears and wet mounts (Ainsworth et al., 1991; Groff and Zinkl, 1999). Examination of blood cells (erythrocytes, leukocytes and thrombocytes) has been widely accepted as an irreplaceable tool for clinicians and researchers in many areas (Densen and Mandell, 1990). Fish leukocytes have been extensively used to investigate immune responses and effects of environmental stress, toxicant exposure, and diseases on individual fish, as well as fish populations and communities (Sniezsko, 1974; Stoskopf, 1993; Zelikoff et al., 2000; Palić et al., 2011).

The aim of this study was to assess the impact of treated wastewaters on native wild Prussian carp inhabiting effluent-receiving waters (receiving municipal and sugar plant treated wastewaters), further downstream waters (County canal), and a detached canal unaffected by the WWTP activities. To that end, general fish health status was determined, and an array of selected plasma biochemical, haematological, oxidative stress and tissue histopathological indices was evaluated. Our hypothesis was that fish captured in both effluent and downstream waters (County canal) would have pronounced biological responses, in relation to season and/or activity of the sugar plant.

\section{Materials and methods}

\subsection{WWTP and the sampling sites}

The study was carried out in spring, summer and fall of 2014. The samplings of water and fish were conducted throughout the treatment process of a Croatian municipal WWTP serving a city of Virovitica, also receiving hospital and sugar plant wastewaters. The sugar plant was active in spring and fall (processing pre-washed sugar cane and sugar beet, respectively), and inactive in summer. Sugar plant con- tributed with $47,925 \mathrm{~m}^{3}$ (15.94\%) in spring and 75,000 $\mathrm{m}^{3}(30.83 \%)$ in fall. Hospital contributed with $4083 \mathrm{~m}^{3}(1.36 \%)$ in spring, $3977 \mathrm{~m}^{3}$ $(2.65 \%)$ in summer, and $4286 \mathrm{~m}^{3}(1.76 \%)$ in fall. Daily total average of treated wastewater was $6880 \mathrm{~m}^{3}$ in spring, $4850 \mathrm{~m}^{3}$ in summer, and $8109 \mathrm{~m}^{3}$ in fall.

WWTP treatment includes primary and secondary processes, including settling tanks, grit chambers, activated sludge biological process, aeration tanks, secondary tanks for removing the biomass and other suspended particles. The resultant final treated effluent is discharged into a natural water canal (site no. 2 in further text). This canal further downstream receives additional communal treated water from a biological treatment plant serving a small suburb, widens to enter a County canal (site no. 3 in further text) which eventually discharges in the river Drava.

Thus, water and fish from three locations were sampled: (1) stream unaffected with the WWTP activities, although not pristine $\left(45^{\circ} 49^{\prime} 33^{\prime \prime} \mathrm{N}-17^{\circ} 22^{\prime} 28^{\prime \prime} \mathrm{E}\right)$, (2) WWTP effluent-receiving canal $\left(45^{\circ} 54^{\prime} 3^{\prime \prime} \mathrm{N}-17^{\circ} 29^{\prime} 6^{\prime \prime} \mathrm{E}\right)$, (3) County canal further downstream, approximately $12 \mathrm{~km}$ from the point of discharge of treated water $\left(45^{\circ} 51^{\prime} 57^{\prime \prime} \mathrm{N}-17^{\circ} 33^{\prime} 21^{\prime \prime} \mathrm{E}\right)$. The County canal is not under regular monitoring for physico-chemical water parameters. It is of interest for the assessment of fish biological responses in a downstream location from the treatment plant. The three sampling sites were chosen as the best representatives of their capacity as unaffected, heavily impacted, and possibly impacted by the treated wastewaters.

\subsection{Fish and tissue processing}

Fish were caught by nets and angling; they were manipulated by the competent authorized persons (licensed veterinarians) in accordance with the provisions of national legislation and the Institute's Bioethical Committee (No. BEP-274/2-2012).

In spring, 24 Prussian carp (Carassius gibelio) (mean weight $498.80 \pm 232.04 \mathrm{~g}$, mean length $213.46 \pm 66.94 \mathrm{~mm}$ ) were captured and examined; in summer 19 Prussian carp (mean weight $112.94 \pm 65.64 \mathrm{~g}$, mean length $173.78 \pm 30.35 \mathrm{~mm}$ ); while in fall 45 Prussian carp (mean weight $127.80 \pm 97.32 \mathrm{~g}$, mean length $170.22 \pm 45.32 \mathrm{~mm}$ ) were examined. Specimens were randomly sampled, transported live to the laboratory and within few hours sacrificed by overdose of tricaine methane-sulfonate (MS-222, Sigma, St. Louis, Missouri, USA).

Wet mounts of gill filaments and skin scrapings were examined under the light microscope. Blood withdrawal and necropsy were performed immediately and tissues (gills, anterior kidney, spleen, liver) were fixed in $4 \%$ neutral buffered formalin, dehydrated through a graded ethanol-xylene series and embedded in paraplast. Sagital and transverse sections $(3-5 \mu \mathrm{m})$ were stained with hematoxylin/eosin (H\&E) and periodic-acid Schiff (PAS) method. Microphotographs were taken with a digital camera DP 70 Olympus ${ }^{\circledR}$ connected to an Olympus ${ }^{\circledR}$ BX51 binocular microscope, and transferred to Microsoft ${ }^{\circledR}$ AnalySIS Soft Imaging System for interpretation. The presence of histopathological alterations was interpreted qualitatively, and the degree of tissue alteration was determined as slight, moderate and severe, based on severity of the lesions.

\subsection{Physico-chemical properties and concentrations of heavy metals in water}

Physico-chemical properties of water were analyzed according to the international standards as follows: determination of electrical conductivity, $\mathrm{pH}$, suspended solids, dissolved oxygen, permanganate index, chemical oxygen demand (COD), biochemical oxygen demand after $\mathrm{n}$ days (BODn), dilution and seeding with allylthiourea, ammo- 
nium and phosphorus with spectrometric method, nitrite, total nitrogen by persulfate digestion method, total phosphorus by ascorbic acid method, nitrate by colorimetry, and cadmium reduction (ISO $7888: 1985$, ISO 10523:2008, ISO 872:2005, ISO 5813:1983, ISO $8467: 1993$, ISO 15705:2002, ISO 5815:1989, ISO 7150-1:1984, ISO 6878:2004, ISO 6777:1984, SM 4500-NO3-E, respectively).

Total metal concentrations of heavy metals $(\mathrm{Cd}, \mathrm{Cr}, \mathrm{Pb}, \mathrm{Hg} \mathrm{Ni}, \mathrm{Zn}$, $\mathrm{Cu}, \mathrm{Fe}$ ) were analyzed according to the international standards as follows: determination of total cadmium, chromium, and lead by atomic absorption spectrometry-graphite furnace technique (ISO 15586:2003, ISO 15586:2004, ISO 15586:2006); determination of mercury by atomic absorption spectrometry (ISO 12846:2012); determination of nickel, zinc, and copper by inductively coupled plasma optical emission spectrometry (ISO 11885:2007, ISO 11885:2011, ISO 11885:2012); determination of iron by spectrometric method using 1,10-phenanthroline (ISO 6332:1988).

\subsection{Haematology, blood biochemistry, oxidative stress}

Blood samples were collected from all sampled fish by caudal vein puncture, immediately after their capture. Long syringes were used for blood withdrawal from the caudal artery and vein. Blood smears were immediately prepared in triplicate and air dried. Blood was collected in tubes coated with anticoagulant lithium heparin, centrifuged at $12,000 \mathrm{~g}$ for $90 \mathrm{~s}$ and resultant plasma was frozen at $-80{ }^{\circ} \mathrm{C}$ until analysis two weeks later.

Blood smears were stained with Diff-quick (Sigma-Aldrich) according to manufacturer's instructions. Leukocyte morphology was examined using bright field microscopy (magnification of $400 \mathrm{X}$ and $1000 \mathrm{X}$ ), and differential count performed on minimum of two hundred cells (neutrophils, lymphocytes, monocytes, not including platelets) in at least 10 visual fields per slide at $400 \mathrm{X}$ magnification. The cell morphology was confirmed by examination at $1000 \mathrm{X}$ under oil. The numbers of counted leukocytes were calculated according to Fudge (2000) in order to obtain the standardized total leukocyte count per $\mu \mathrm{L}$ of blood and their ratio (as \%).

Heparinized microhaematocrit capillaries were filled with blood, sealed with clay and centrifuged for $120 \mathrm{~s}$ at $12,000 \mathrm{~g}$ within $20 \mathrm{~min}$ from collection. The percentage of packed cells to total volume was determined by direct measurement on StatSpin microhaematocrit capillary tube reader. Haematocrit (Hct) was determined as packed cells volume by the microhaematocrit method (Wedemeyer and Yasutake, 1977).

In blood plasma, concentrations of glucose (GLU), urea (URE), creatinine (CRE), cholesterol (CHOL), triglyceride (TRIG), total proteins (TP), albumin (ALB) and activity of alanine aminotransferase (ALT), alkaline phosphatase (ALP), gamma-glutamyl transferase (GGT) were determined by Beckman Coulter commercial kits (Olympus Life and Material Science Europe, Ireland) on the Olympus AU 640 biochemistry analyzer (Olympus, Japan).

The activity of superoxide dismutase (SOD) and glutathione peroxidase (GSH-Px) were determined by Randox commercial kits on the Olympus AU 640 biochemistry analyzer. Paraoxonase activity (PON 1) in serum was assayed by modified method of hydrolysis of paraoxon described by Charlton-Menys et al. (2006) on the Olympus AU 640. Enzyme activity was presented in U/L ( $1 \mu \mathrm{mol} p$-nitrophenol formed $/ \mathrm{min} / \mathrm{L}$ ).

\subsection{Statistical analysis}

Statistical analyses were performed by SigmaStat and SigmaPlot Statistical Software ver. 11.0 (Jandel Corp., San Rafael, California).
Plasma biochemistry data were subjected to logarithmic transformation. Intergroup differences of blood parameters were assessed using $t$-test for parametric and Mann-Whitney Rank Sum Test for non-parametric data. Correlations between measured biochemical parameters were determined by Spearman Rank Order Correlation. Leukogram data, presented as mean \pm standard error of the mean (SEM), were analyzed using $t$-test and one-way ANOVA followed by the Tukey test. Student's $t$-test was used to identify differences in means, one-way ANOVA was used in order to identify differences in cell metrics, Tukey test was used to identify site and seasonal differences in leukogram readings. The $p<0.05$ was regarded as statistically significant for all comparisons.

All data were also subjected to multivariate analysis in order to extract variables or important related information, to identify possible clusters, and to identify trends between samples and/or variables. Factor analysis (FA) was the first step in the classification process, aiding in identification of significant variables and reduction of the original data set. The next step was the Principal component analysis (PCA), usually performed by pattern recognition methods (Bosque-Sendra et al., 2012), in order to effectively reduce redundant information (Hashem Sweidan et al., 2015). Finally, the Discriminant analysis (DA) was used to evaluate the classification and to distinguish measured variables relative to seasons and sampling sites.

\section{Results}

\subsection{Water quality and general fish health status}

Physicochemical and heavy metal properties of water are presented in Tables 1 and 2. In spring in the effluent-receiving canal (sugar cane processing), $\mathrm{Pb}, \mathrm{Ni}, \mathrm{Zn}, \mathrm{Cu}$, suspended solids and BODn were the highest measured. In summer in the effluent-receiving canal (inactivity of the sugar plant), Fe, COD and COD-Mn, as well as total nitrogen and phosphorus were the highest measured. In fall in the same canal, ammonium, nitrite and nitrate were the highest measured.

Rainfall and leachate waters contributed to the total processed waters with $26.10 \%, 48.67 \%$ and $36.37 \%$ in spring, summer and fall, respectively.

According to the external gross signs and necropsy findings from fish captured over the seasons in the three representative water bodies, no major symptoms of diseases were evident. Gills from carp fished out of the effluent-receiving waters in all seasons showed haemorrhagic changes, associated with extensive mucus secretions and swelling. In all sampling stations and over all seasons, monogenean gill flukes were the most prevalent of all parasites. In spring and summer, the degree of monogenean infestations was greatest in fish from the County canal, while in fall it was predominant in the effluent fish. In spring, fish from the unaffected stream had a low parasitic infestation of gills with Dactylogyrus spp. while those from the County canal carried an intermediate load, mainly Dactylogyrus spp. on gills and Thelohanellus spp. on opercula, skin and fins. In summer, monogenean Dactylogyrus spp. was the only external parasite found, and only on fish in the County canal as an intermediate load. In fall, only fish from the effluent-receiving canal carried a low burden of parasites, mainly Dactylogyrus spp. and Gyrodactylus spp. on gills and skin, respectively.

\subsection{Histopathology}

Histopathological findings of effluent fish mostly revealed structural and functional alterations of gill tissues, related extensively to the secondary lamellae (Fig. 1), while kidney lesions related to alter- 
Table 1

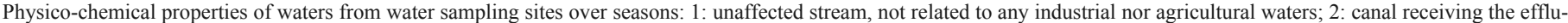
ent, entering the wider County canal; 3: County canal further downstream, entering the Drava river.

\begin{tabular}{|c|c|c|c|c|c|c|c|c|c|}
\hline \multirow[t]{2}{*}{ Parameters measured (with limits of detection) } & \multicolumn{3}{|c|}{ 1. Unaffected stream } & \multicolumn{3}{|c|}{ 2. Canal receiving the effluent } & \multicolumn{3}{|c|}{ 3. County canal further downstream } \\
\hline & Spring & Summer & Fall & Spring & Summer & Fall & Spring & Summer & Fall \\
\hline Temperature ${ }^{\circ} \mathrm{C}$ & 13.90 & 17.70 & 13.80 & 18.60 & 16.50 & 13.80 & 16.50 & 22.00 & 9.30 \\
\hline Dissolved oxygen $\left(0.1 \mathrm{mg} \mathrm{O}_{2} / \mathrm{L}\right)$ & 9.66 & 8.14 & 8.91 & 2.26 & 5.11 & 1.23 & 9.29 & 4.37 & 2.48 \\
\hline Oxygen saturation $\%$ & 94.90 & 86.40 & 86.70 & 24.60 & 52.50 & 22.60 & 95.90 & 50.90 & 21.60 \\
\hline $\mathrm{pH}$ & 8.13 & 7.94 & 8.08 & 7.89 & 7.70 & 8.05 & 7.65 & 7.31 & 7.50 \\
\hline Suspended solids $(0.01 \mathrm{mg} / \mathrm{L})$ & 37.70 & 27.90 & 17.70 & 171.00 & 56.30 & 8.50 & 8.60 & 9.00 & 1.80 \\
\hline $\mathrm{COD}\left(5 \mathrm{mg} \mathrm{O}_{2} / \mathrm{L}\right)$ & 43.16 & 42.69 & - & 57.55 & 64.16 & - & 18.49 & 23.67 & 18.77 \\
\hline COD-Mn $\left(0.01 \mathrm{mg} \mathrm{O}_{2} / \mathrm{L}\right)$ & 15.63 & 15.70 & 9.18 & 30.64 & 31.43 & 18.14 & 11.93 & 10.09 & 11.64 \\
\hline $\operatorname{BODn}\left(2 \mathrm{mg} \mathrm{O}_{2} / \mathrm{L}\right)$ & 19.85 & 19.00 & 10.75 & 48.26 & 41.66 & 17.50 & 12.84 & 4.73 & 7.60 \\
\hline Ammonium $\left(0.01 \mathrm{mg} \mathrm{NH}_{4}-\mathrm{N} / \mathrm{L}\right)$ & 0.02 & 0.36 & 0.49 & 8.40 & 4.30 & 20.00 & 0.05 & 0.59 & 0.52 \\
\hline Nitrite $(0.001 \mathrm{mg} \mathrm{NO}-\mathrm{N} / \mathrm{L})$ & 0.01 & 0.03 & 0.027 & 0.40 & 0.85 & 1.48 & 0.04 & 0.01 & 0.077 \\
\hline Nitrate $(0.1 \mathrm{mg} \mathrm{NO}-\mathrm{N} / \mathrm{L})$ & 0.30 & 2.60 & 1.30 & 1.30 & 9.30 & 13.40 & 1.20 & 1.80 & 2.90 \\
\hline Total nitrogen (1 mg N/L) & 1.74 & 4.20 & - & 11.80 & 15.20 & - & 10.70 & $<5.00$ & $<5.00$ \\
\hline Phosphate $(0.001 \mathrm{mg} \mathrm{P} / \mathrm{L})$ & 0.09 & 0.20 & 0.10 & 0.97 & 2.30 & 0.63 & 0.09 & 0.20 & 0.83 \\
\hline Total phosphorus $(0.001 \mathrm{mg} \mathrm{P} / \mathrm{L})$ & 0.17 & 0.25 & 0.15 & 1.49 & 2.80 & 0.89 & 0.15 & 0.22 & $<1.00$ \\
\hline
\end{tabular}

Table 2

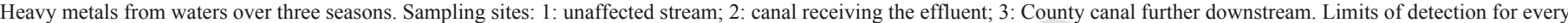
heavy metal measured are in parentheses in the first column.

\begin{tabular}{|c|c|c|c|c|c|c|c|c|c|}
\hline \multirow[t]{2}{*}{ Concentration in $\mu \mathrm{g} / \mathrm{L}$ (with limits of detection in $\mu \mathrm{g} / \mathrm{L}$ ) } & \multicolumn{3}{|c|}{ 1. Unaffected stream } & \multicolumn{3}{|c|}{ 2. Canal receiving the effluent } & \multicolumn{3}{|c|}{ 3. County canal further downstream } \\
\hline & Spring & Summer & Fall & Spring & Summer & Fall & Spring & Summer & Fall \\
\hline Iron $(1 \mu \mathrm{g} / \mathrm{L})$ & 8388.00 & 984.00 & 750.00 & 703.00 & 720.00 & 140.00 & 128.00 & 490.00 & 464.00 \\
\hline Cadmium $(0.1 \mu \mathrm{g} / \mathrm{L})$ & 0.06 & 0.33 & 0.16 & 0.80 & $<0.20$ & $<0.10$ & 0.05 & $<0.20$ & 0.18 \\
\hline Chromium $(0.5 \mu \mathrm{g} / \mathrm{L})$ & 6.08 & 7.53 & 4.03 & 7.70 & $<1.00$ & $<1.00$ & 12.91 & 1.30 & 2.72 \\
\hline Mercury $(0.2 \mu \mathrm{g} / \mathrm{L})$ & $<0.20$ & 2.99 & 0.94 & 0.87 & 1.74 & $<0.20$ & 0.45 & $<0.20$ & $<0.2$ \\
\hline Lead $(1 \mu \mathrm{g} / \mathrm{L})$ & 1.86 & 4.56 & 5.86 & 5.58 & 0.48 & 1.97 & 2.14 & 0.53 & 2.38 \\
\hline Nickel $(1.5 \mu \mathrm{g} / \mathrm{L})$ & 10.00 & 6.00 & 4.65 & 31.00 & 4.00 & 2.94 & 8.00 & 2.00 & $<1.00$ \\
\hline $\operatorname{Zinc}(3 \mu \mathrm{g} / \mathrm{L})$ & 23.00 & 43.00 & 2.58 & 90.00 & 28.00 & 7.52 & 27.00 & 30.00 & 16.15 \\
\hline Copper $(1.5 \mu \mathrm{g} / \mathrm{L})$ & 56.00 & 34.00 & 7.75 & 270.00 & 27.00 & 5.13 & 61.00 & 20.00 & 4.14 \\
\hline
\end{tabular}

ations of nephrons and tubular system (Fig. 2). In effluent fish, karyolysis, binuclear hepatocytes, and distension of liver sinusoids $(55 \%$ and $65 \%$ of samples, respectively) were noted (Fig. 3). Spleen alterations were noted in effluent and downstream County canal fish (Fig. $4)$. Fish from the downstream County canal had hyperplastic and hypertrophied gills $(69 \%)$.

In spring, lamellar fusion was observed (70\%), as well as spleen alterations, in form of intracellular vacuoles and granulomatous lesions in fish from the effluent ( $23 \%$ and $15 \%$, respectively) and County canal (18\% and $13 \%$, respectively) (Fig. 4). In summer, the most pronounced lesions were atrophy and necrosis of lamellae (75\%). Different stages of atrophy and necrosis of glomeruli were noted over seasons, with most pronounced changes in summer $(55 \%$ and $45 \%$, respectively) and fall (60\% and 54\%, respectively) (Fig. 2). Carp liver tissues exhibited alterations predominantly in summer and fall, mainly in effluent fish. In fall, hypertrophy of epithelial and interlamellar cells was also evident (35\%).

\subsection{Haematology, blood biochemistry and oxidative stress}

Leukocyte counts were significantly different between the three localities and sampling seasons (Table 3). The unaffected stream fish had significantly different granulocyte numbers between spring and fall sampling seasons. At the effluent site, fish had similar leukograms across the sampling seasons. The downstream County canal fish had significant fluctuation in leukograms between sampling seasons.

In spring, total leukocyte numbers were significantly higher in fish caught in the County canal, primarily due to increased lympho- cyte numbers when compared to fish sampled in unaffected stream and effluent. In summer, County canal fish continued to display significantly higher total leukocyte numbers, but in this season it was due to increased granulocyte numbers. During fall, fish from the unaffected stream showed significantly higher leukocyte numbers due to increased granulocyte counts.

The haematocrit values are presented in Table 4, but mostly showed no significant relationships between seasons/locations. The Spearman Rank Order Correlation demonstrated that haematocrit variables for County canal fish in summer tend to decrease while spring variables increase and vice versa (negative correlation coefficient and $p$ value below 0.05 ) (see Table 5).

The values of GGT, GSH-Px and PON 1 were not measurable in most of the tested samples, probably due to haemolysis, and are therefore not presented. A general comparison of the plasma URE, CRE, TP, ALB, GLU, ALT, ALP, TRIG, CHOL, and SOD values of Prussian carp in all seasons are presented in Fig. 5. One Way Analysis of Variance established the significance $(p<0.05)$ for CHOL in the effluent-receiving canal vs. County canal in fall, and CHOL in unaffected canal in summer $v s$. County canal in fall. Significant differences were also noted for CRE and TRIG in the unaffected canal fish (spring $v s$. fall specimens), for CRE in the unaffected (spring) vs. effluent canal (fall). TRIG also had significant differences in the effluent canal (spring vs. fall specimens). The Spearman Rank Order Correlation demonstrated that pairs of variables with $p$ values below 0.05 and positive correlation coefficients, such as SOD County canal (spring/ summer) tend to increase together.

The input matrix for multivariate analysis consisted of 17 variables (URE, CRE, TP, ALB, GLU, ALT, ALP, TRIG, CHOL, SOD, 

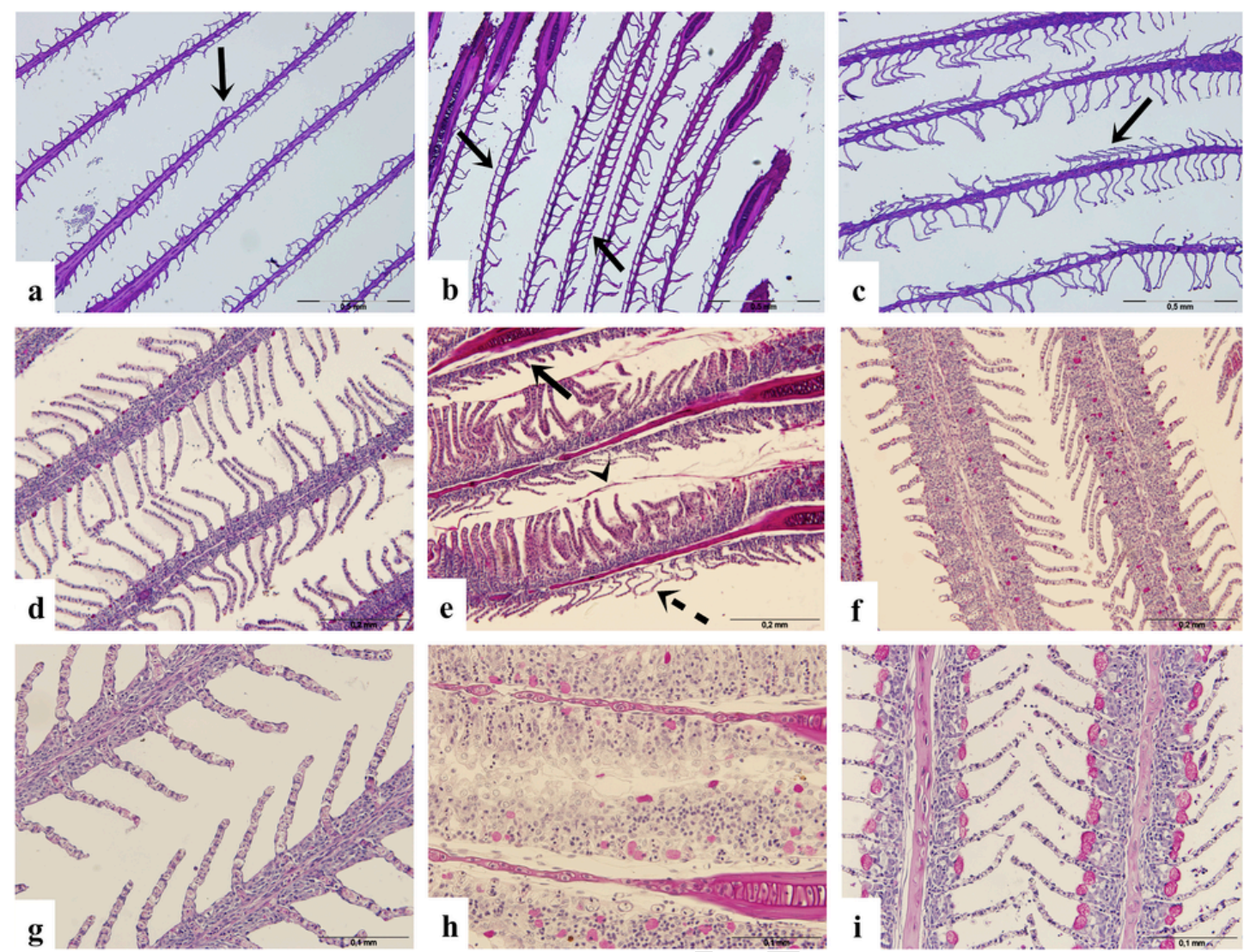

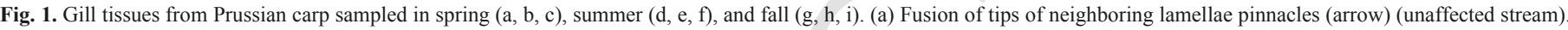

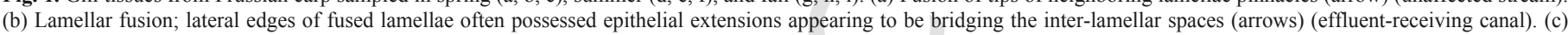

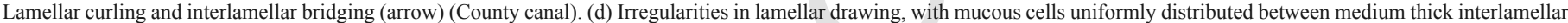

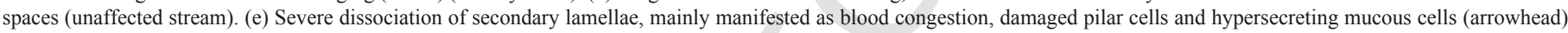

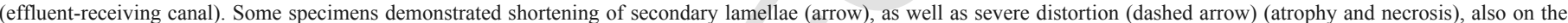

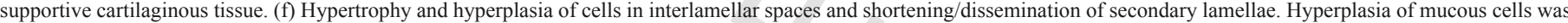

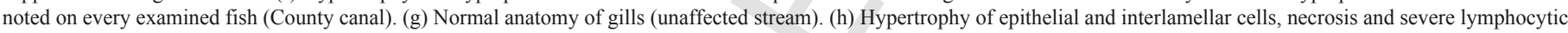
infiltration; intralamellar oedema and detachment from primary lamellae (effluent-receiving canal). (i) Hyperplastic and hypertrophied mucous cells in gills (County canal).

HCT, lymphocytes - LYM, polymorphonuclears - PMN, monocytes - MON, leukocytes - LEUK, length, weight), classified for each fish from different locations over seasons. Variables were reduced with the factor analysis (FA) which identified following parameters as significant for the respective location: (A) unaffected stream - URE, GLU, ALT, TRIG, SOD, HCT, LYM, PMN, LEUK; (B) canal receiving the effluent - URE, CRE, TP, ALB, GLU, ALT, ALP, TRIG, CHOL, SOD, weight; (C) County canal further downstream - TP, ALB, TRIG, CHOL, length and weight. The PCA score plots for these parameters (Fig. 6) demonstrate that the groupings were based on high percentage of the explained variance in all cases $(77.07 \%$ for $\mathrm{A}$, $85.63 \%$ for B, and $82.34 \%$ for C). A cross-section of observed sets of significant parameters was conducted and reduced to the following nine parameters: URE, TP, ALB, GLU, ALT, TRIG, CHOL, SOD and weight. Using those parameters, we were able to group the samples according to the fish sampling sites with the PCA showing $100 \%$ of the explained variance in all cases. Those parameters allowed their discrimination (DA) with the success of $85 \%$, but when we used the mean values per season, the classification for locations was 100\% (Fig. 7).

\section{Discussion}

Chemicals in the environment usually appear as complex mixtures with antagonistic, additive or synergic biological effects (Garmendia et al., 2015). In an environment where they occur in chronic and sublethal concentrations, changes in function and structure of fish tissues are encountered more than their mass mortality (Flores-Lopes and Thomaz, 2011). A sequence of biological responses can be triggered by multiple contaminant stress, and each of those may be used as a biomarker of effect, associated with health impairment or disease (van der Ost et al., 2003). Effluent from the WWTP under this study, discharging into a relatively small receiving canal, had a marked effect on Prussian carp community collected from the effluent canal and a downstream location (County canal). The results of the study support the hypothesis, indicating that fish biological responses related to the treated wastewater reach far downstream from the treatment plant and depend on season and/or activity of the sugar processing plant.

Volumes of wastewater produced in sugar beet processing can be considerable, with a substantial polluting potential, especially regarding the large quantity of soil and trash associated with mechanized harvesting and harvesting in wet weather, that is brought into the fac- 

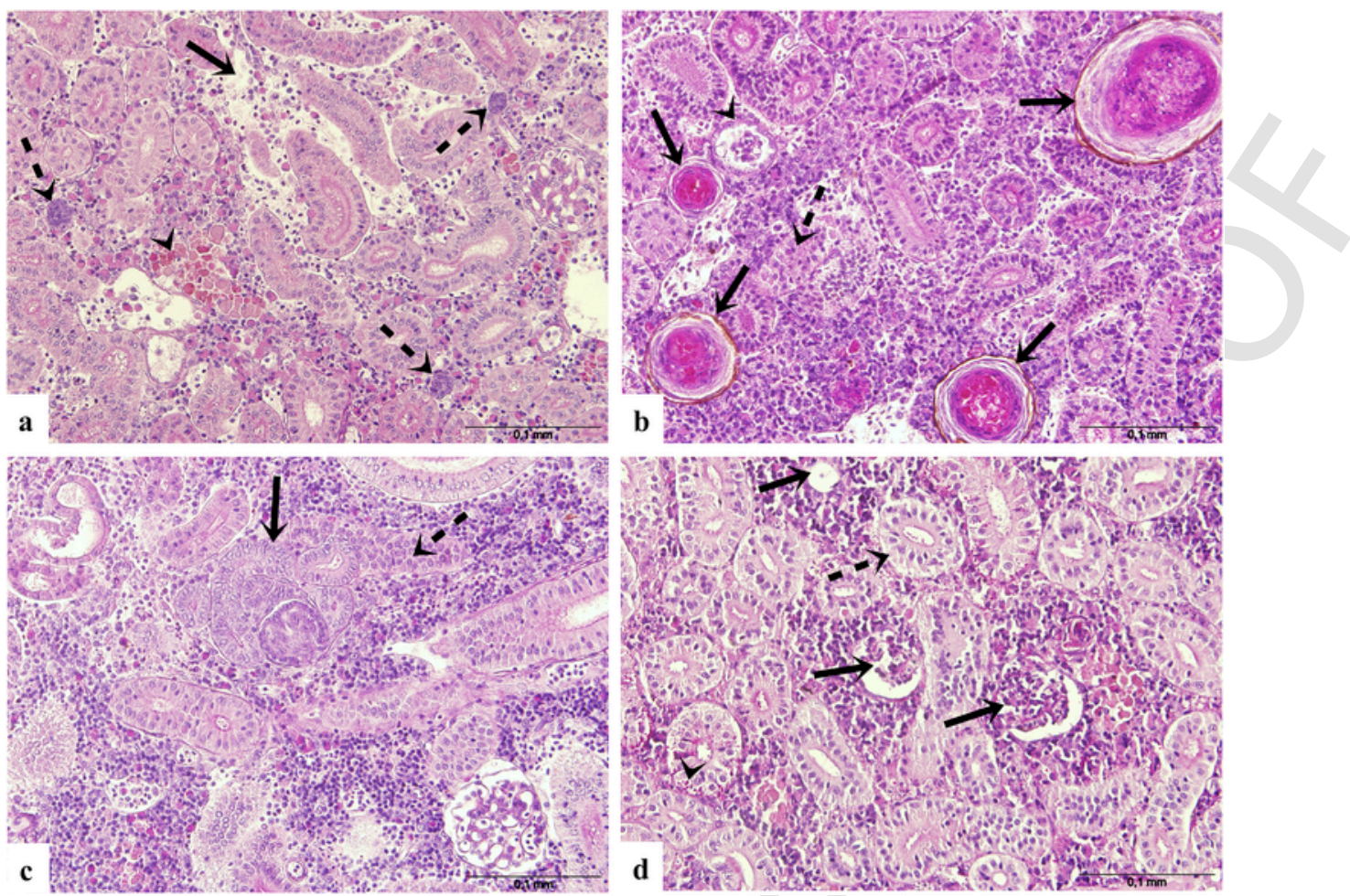

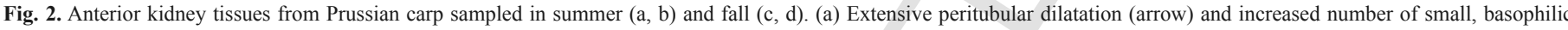

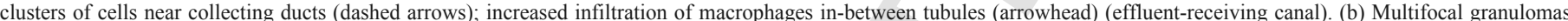

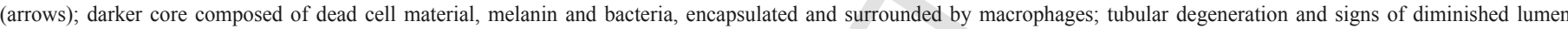

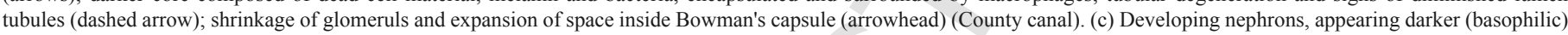

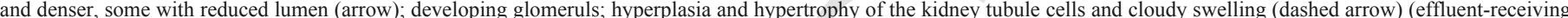

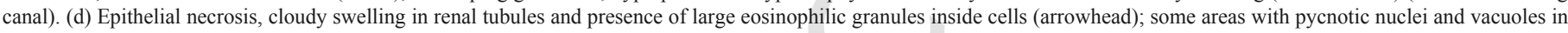
cytoplasm (dashed arrow); different stages of atrophy and necrosis of glomeruls (arrows) (County canal).

tory with the root crop, as a great quantity of mud enters the system through the initial beet washing and fluming process (Cheesman, 2004). Consequently, the significantly higher suspended solids, COD-Mn, BODn, and ammonium concentrations (Table 1) were measured in the effluent. Notably, the sugar cane processing did not have the same impact on the effluent waters as the sugar beet processing, mainly due to the fact that it was prewashed elsewhere prior to production. However, it particularly affected both the effluent-receiving canal and downstream County canal with heavy metal pollutants, namely $\mathrm{Cu}, \mathrm{Zn}, \mathrm{Cr}, \mathrm{Ni}$, all known depressants of fish immune capabilities (Javed and Usmani, 2015a). Sugar beet processing yielded the extreme ammonium, nitrate, nitrogen, phosphate concentrations in the effluent-receiving canal when related to other seasons and water bodies, and also when related to the work of El-Shafai et al. (2004). Sugar cane processing, on the other hand, resulted in high suspended solids, BOD, total nitrogen, and total phosphorus in the effluent-receiving canal. Elevated nitrogen and phosphorus may result in overgrowth of algae, decreasing the dissolved oxygen content of the water, thereby harming or killing fish and other aquatic species (Sahu and Chaudhari, 2015).

\subsection{Water quality and parasitic infestations, haematology and blood biochemistry}

Fish captured at the sampling sites did not vary significantly in external gross signs and necropsy findings. Downstream Prussian carp, however, suffered from a heavier parasitic infestation than fish captured in the effluent-carrying canal, which could be attributed to their possible migration over the water bodies in pursuit of the more favorable feeding locations. Monogenean gill flukes were the most prevalent of all parasites found in this study, however they showed no site preference, also noted by Billard and Khan (2003) who established that gill parasites of fish exposed to municipal and industrial effluents had no site difference. Furthermore, Kelly and Janz (2008) found that the degree of infestation, as measured by the abundance and biomass of intestinal parasites and the abundance of monogeneans on pike (Esox lucius) gills, was greatest in reference fishes and intermediate in low-exposure pike, whereas high-exposure fishes harbored no parasites, which corresponds well with our findings. That could be explained by the finding that low concentrations of the WWTP pollutants are not directly toxic to the monogeneans (dactylogyrids in particular), while high concentrations result in mortality of parasites and produce a reduction of infestation levels (Siddal et al., 1997). Higher parasite infestation in fish in the downstream County canal might also be correlated with the higher density of fish in that canal when compared with the effluent fish, particularly in spring. One of the explanations is their moving to more favorable conditions, as suspended solids (in particular), COD, COD-Mn, BODn, ammonium, nitrite and total phosphorus were several-fold higher in the effluent-receiving waters, with significantly lower dissolved oxygen content. Water temperature was not significantly related with the monogenean abundance although low to intermediate infestations were noted in spring and summer. Temperature was previously shown as only one of the factors influencing proliferation of monogenean biomass, as $\mathrm{pH}$, dissolved oxygen, ammonia and other water properties might mask the effect of temperature (Rakauskas and Blaevièius, 2010). There was, however, a negative correlation between monogenean prevalence and the concentration of lead in waters, particularly 

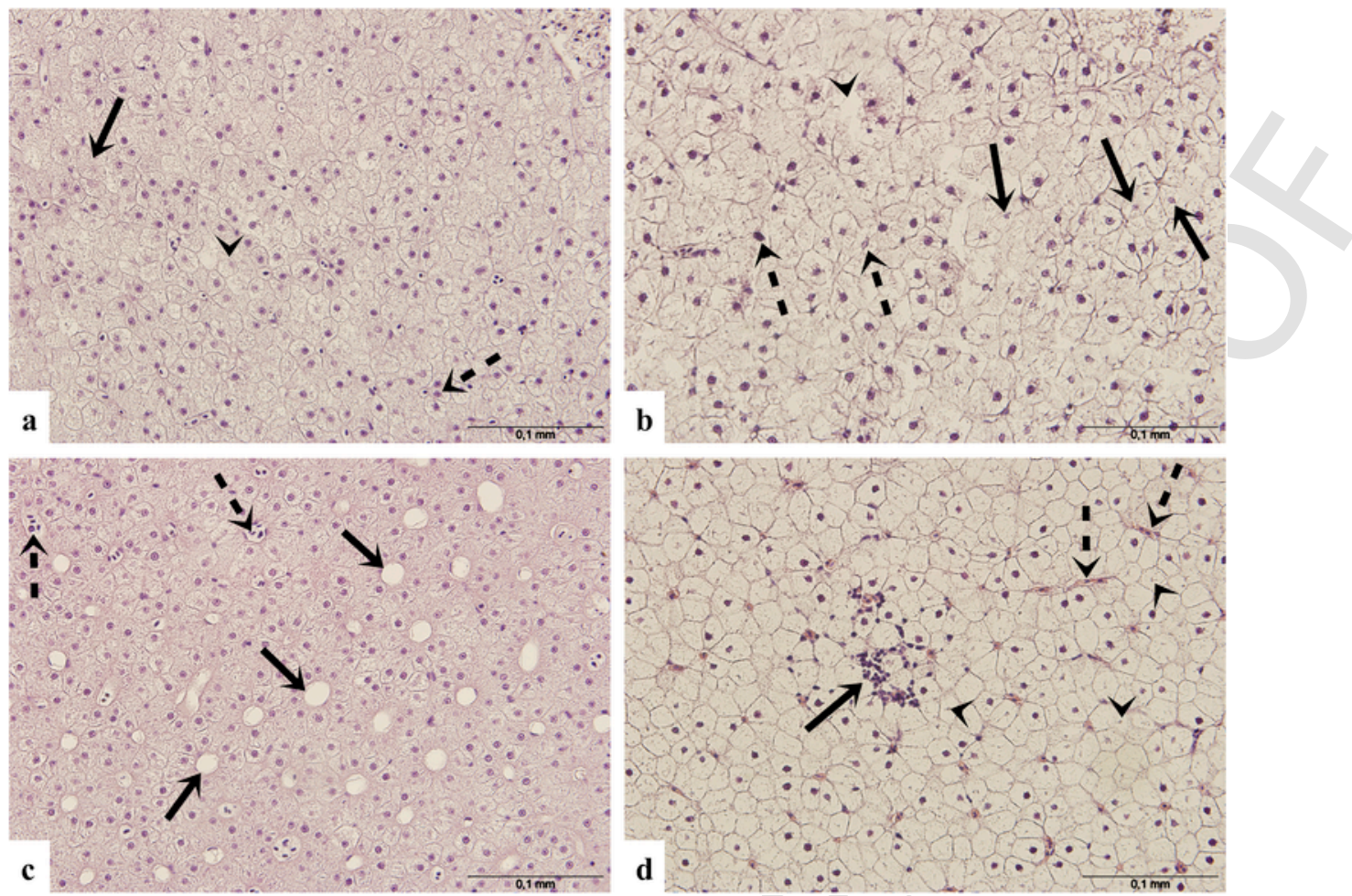

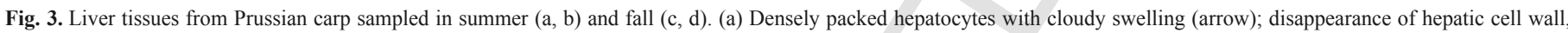

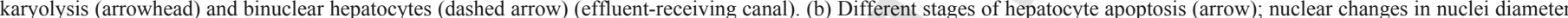

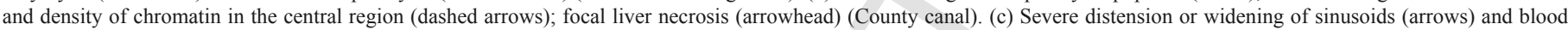

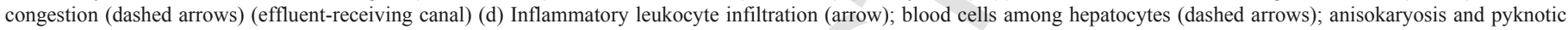
nuclei (arrowheads) (County canal).

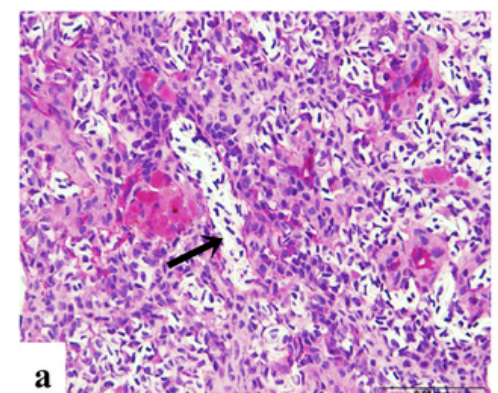

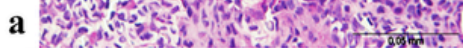
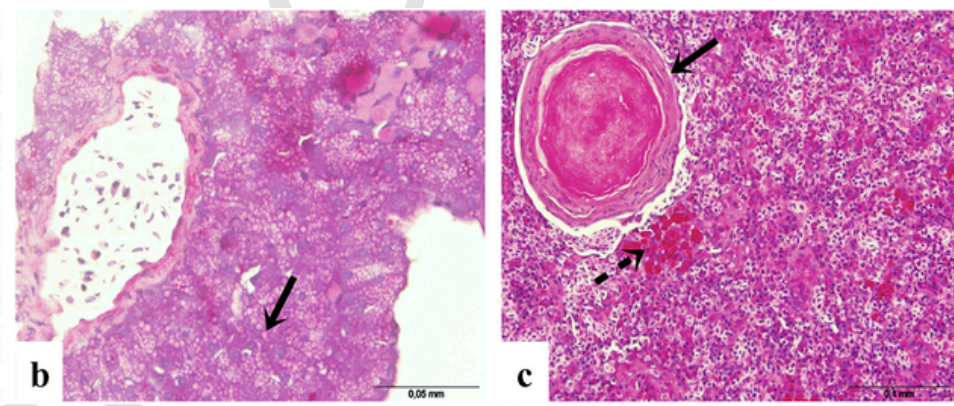

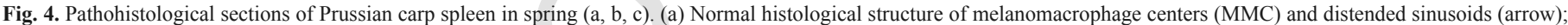

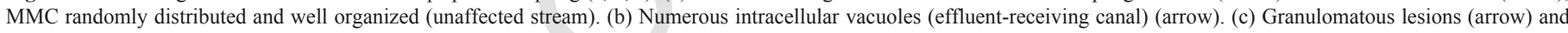
presence of increased number and size of MMC (dashed arrow) (County canal).

remarkable in spring (effluent-receiving waters, $5.58 \mu \mathrm{g} / \mathrm{L}$ ) and summer (unaffected stream, $4.56 \mu \mathrm{g} / \mathrm{L}$ ), as previously established by Bayoumy et al. (2008). The same authors also noted a significant positive correlation between monogenean infestation and concentration of nickel in the water, but we did not observe any such connection. Pollutants such as heavy metals reduce the immunological capabilities of fish host, rendering them more susceptible to parasites (Overstreet, 1993), monogenean carp infestations thus serving as auxiliary bioindicator models.

Haematology of fish, specifically leukograms, can be a valuable clinical and research tool, providing that standardized technique is applied, comparisons between non-affected control and treatment groups exist, or appropriate set of reference values is available for the species (Clauss et al., 2008). There is little available data about Pruss- ian carp leukocyte intervals, however reported values are in accordance with numbers observed during our study (Aksentijević, 2010; Farahi et al., 2011). Increased leukocyte (lymphocyte) counts observed in fish collected in County canal during spring sampling (highest overall $\mathrm{Cr}$ concentration $12.9 \mu \mathrm{g} / \mathrm{L}$ ) are also consistent with increased parasitic loads and gill pathology (Roberts, 2001). Summer samples showing overall decrease of lymphocites, alongside relative increase of granulocytes in the effluent canal, are also indicative of neutrophilia due to heavy metal ( $\mathrm{Pb}$ and $\mathrm{Cd}$ ) exposure (Zelikoff, 1993; Witeska, 2005). Increased numbers of granulocytes in the County canal in summer could suggest transient neutrophilia due to stressful conditions and increased parasite loads (Alvarez-Pellitero, 2008). Generally, a fish stress leukogram reflects leukopenia with lymphopenia and granulocytosis. Such changes may persist for sev- 
Table 3

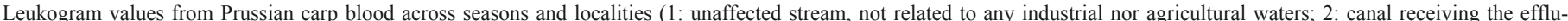

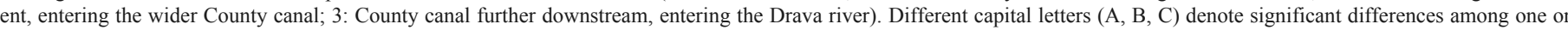

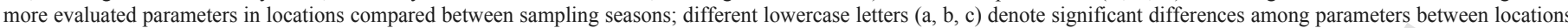

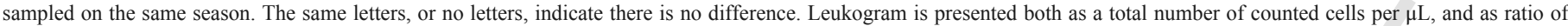

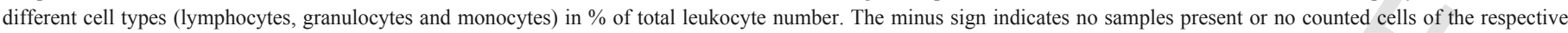
type (unaffected stream fish in summer, monocytes and granulocytes in summer and fall, respectively).

\begin{tabular}{|c|c|c|c|c|c|c|c|c|}
\hline & \multicolumn{3}{|l|}{ Spring } & \multicolumn{2}{|l|}{ Summer } & \multicolumn{3}{|l|}{ Fall } \\
\hline & 1. Stream ${ }^{\mathrm{A}}$ & 2. Effluent ${ }^{\mathrm{A}}$ & 3. Canal $^{\mathrm{B}}$ & 1. Effluent ${ }^{\mathrm{C}}$ & 2. $\mathrm{Canal}^{\mathrm{D}}$ & 1. Stream ${ }^{\mathrm{E}}$ & 2. Effluent ${ }^{\mathrm{A}}$ & 3. $\mathrm{Canal}^{\mathrm{A}}$ \\
\hline Total Leukocytes $\left(\mu \mathrm{L}^{-1}\right)$ & $5840 \pm 809^{\mathrm{a}}$ & $4400 \pm 353^{\mathrm{a}}$ & $13400 \pm 760^{b}$ & $5900 \pm 898^{\mathrm{a}}$ & $19778 \pm 1949^{b}$ & $42840 \pm 5013^{\mathrm{a}}$ & $2467 \pm 565^{\mathrm{b}}$ & $4378 \pm 506^{\mathrm{b}}$ \\
\hline Lymphocytes $\left(\mu \mathrm{L}^{-1}\right)$ & $3840 \pm 475^{\mathrm{a}}$ & $3240 \pm 260^{\mathrm{a}}$ & $11986 \pm 740^{b}$ & $1700 \pm 449$ & $3022 \pm 384$ & $5440 \pm 1029^{a}$ & $1333 \pm 274^{b}$ & $4378 \pm 506^{\mathrm{a}}$ \\
\hline$\%$ & $72.5 \pm 3.0$ & $74.2 \pm 2.7$ & $74.1 \pm 1.6$ & $28.8 \pm 3.7$ & $23.5 \pm 2.0$ & $11.6 \pm 1.2$ & $73.2 \pm 10.9$ & $88.7 \pm 1.8$ \\
\hline Granulocytes $\left(\mu \mathrm{L}^{-1}\right)$ & $1720 \pm 265$ & $760 \pm 92$ & $1585 \pm 103$ & $3900 \pm 618^{\mathrm{a}}$ & $16600 \pm 1826^{\mathrm{b}}$ & $36800 \pm 4338^{\mathrm{a}}$ & $1133 \pm 488^{b}$ & - \\
\hline$\%$ & $25.4 \pm 3.7$ & $19.2 \pm 2.1$ & $13.3 \pm 0.9$ & $63.1 \pm 5.2$ & $73.0 \pm 2.4$ & $86.2 \pm 1.1$ & $26.8 \pm 16.3$ & - \\
\hline Monocytes $\left(\mu \mathrm{L}^{-1}\right)$ & $280 \pm 93$ & $400 \pm 91$ & $757 \pm 40$ & $300 \pm 75$ & $156 \pm 29$ & $600 \pm 88$ & - & $422 \pm 70$ \\
\hline$\%$ & $2.5 \pm 1.8$ & $6.9 \pm 1.4$ & $6.0 \pm 0.3$ & $8.1 \pm 1.8$ & $3.5 \pm 0.9$ & $2.2 \pm 0.4$ & - & $11.3 \pm 1.8$ \\
\hline
\end{tabular}

\section{Table 4}

Haematocrit values from Prussian carp blood across the seasons: 1: unaffected stream, not related to any industrial nor agricultural waters; 2 : canal receiving the effluent, entering the wider County canal; 3: County canal further downstream, entering the Drava river.

\begin{tabular}{llll}
\hline & $\begin{array}{l}\text { 1. Unaffected } \\
\text { stream }\end{array}$ & $\begin{array}{l}\text { 2. Canal receiving the } \\
\text { effluent }\end{array}$ & $\begin{array}{l}\text { 3. County canal further } \\
\text { downstream }\end{array}$ \\
\hline Spring & $33.60 \pm 14.52$ & $42.00 \pm 8.37$ & $47.14 \pm 7.26$ \\
Summer & $29.00 \pm 13.21$ & $27.20 \pm 18.36$ & $37.56 \pm 10.08$ \\
Fall & $36.06 \pm 11.48$ & $27.86 \pm 13.85^{*}$ & $42.44 \pm 6.38^{*}$ \\
\hline
\end{tabular}

Data are mean \pm S.D. Data with * indicate significant difference at $p<0.05$.

eral days after the stressor is removed (Dove and Arnold, 2008). Significant decrease in granulocytes observed in fall sampling (during sugar beet processing) of fish at the effluent-receiving canal, compared to reference, could indicate immunosuppression due to poor water quality (Dunier, 1996; Arkoosh et al., 1998). Although the PCA analysis proved leukocytes, polymorphonuclears and lymphocytes as significant variables only in fish from the unaffected spring in fall, the overall observed significant differences and seasonal/location changes in the leukograms of the sampled fish were in accordance with other monitored parameters during this study.

The baseline haematocrit values of carp have been established at $28-32 \%$, and tending to increase under stress and elevated temperatures (Hrubec and Smith, 2000; Stoskopf, 1993). The cause for increase of Hct values during acute hypoxic exposure is water loss from the blood and release of cells from depots in liver and spleen in order to increase the oxygen-carrying blood capacity (Heath, 1995). Although no major significances were found between the Prussian carp groups under survey, the highest overall Hct values were recorded in spring in downstream County canal, which coincided with the highest overall measured $\mathrm{Cr}(12.9 \mu \mathrm{g} / \mathrm{L})$. Chromium was previously shown to increase Hct, serum glucose and proteins in carp (Al-Alkel and Shamsi, 1996). Fish might also increase their metabolic rate and consequently Hct values if changes in water quality or destruction of breeding niches occur (Jawad et al., 2004). Under high nitrite exposure, for example, the high activity of the methaemoglobin-reductase system converting methaemoglobin to haemoglobin results in shortening the normal life span of red blood cells, followed by an increase in haematocrit (Kroupova et al., 2005). Our effluent fish had the highest Hct values in spring (sugar cane processing), but these waters also had the highest of all measured copper concentrations $(270 \mu \mathrm{g} / \mathrm{L})$, similar to the findings of Mustafa et al. (2012), where the carp Hct values increased significantly in the hypoxic fish with the high $\mathrm{Cu}$ exposure level. The high suspended solids,
COD-Mn, BODn, and ammonium values in the effluent-receiving canal in spring (when the sugar plant was actively processing sugar cane), along with the low dissolved oxygen values, surely contributed to the impaired osmoregulation and damage to gill cells. Water quality thus caused additional stress with possible adrenergic stimulation of the erythropoietic organs causing them to contract and release stored erythrocytes into circulating blood (Mustafa et al., 2012).

Although having a high tolerance to heavy metals by a mechanism of avoidance of hypoxic status and resistance of severe plasma ions loss (Schjolden et al., 2007), elevated heavy metal concentrations $(\mathrm{Cr}$ $7.7 \mu \mathrm{g} / \mathrm{L}, \mathrm{Pb} 5.58 \mu \mathrm{g} / \mathrm{L}$, Ni $31 \mu \mathrm{g} / \mathrm{L}, \mathrm{Zn} 90 \mu \mathrm{g} / \mathrm{L}, \mathrm{Cu} 270 \mu \mathrm{g} / \mathrm{L})$ might have contributed to increase of some carp plasma metabolites in our study (TRIG, CHOL, ALB, URE, TP in the effluent fish in spring). The evaluation of plasma biochemistry can provide essential data on the physiological status of fish, and fish under stress may have significant changes in plasma biochemistry (Chen et al., 2003). Blood GLU elevations may indicate a generalized stress response to a variety of environmental conditions, while a rate of change in environmental oxygen has effects on changes in plasma GLU, as hypoxic stress induces hyperglycemia (Heath, 1995). Plasma proteins coupled with GLU, TRIG and CHOL are excellent indicators of stress in fish (Wells and Pankhurst, 1999). The complex mixture of proteins in fish plasma largely originates from the liver, and some of these bind copper and zinc, although there might be a binding protein for each essential trace metal (Heath, 1995). Increased concentrations of TP can be caused by structural liver alterations (Čož-Rakovac et al., 2005). Also, as most urea in fish is produced by the liver, elevated URE is not necessarily indicative of renal disease, but is more likely associated with gill or liver impairment (Stoskopf, 1993), as noted in fish captured from the effluent in spring (sugar cane processing).

Plasma CHOL significantly varied in fall (effluent-receiving canal vs. downstream County canal), when its concentrations were the lowest and the highest of all seasons and locations, respectively. Seasonal CHOL variations in carp were not previously established (Svetina et al., 2002). Levels of CHOL in fish blood are moderately sensitive to the presence of pollutants, and seem to depend on their concentration, which affects osmoregulation. Sublethal concentrations of organic pesticides decrease CHOL in carp (Gluth and Hanke, 1985), as well as a long-term exposure of carp to mercury (Heath, 1995). Similar trend was also noted in plasma TRIG, which was the lowest in effluent fish in fall. Such a drastic drop might also be a consequence of the feed shortage in the effluent-receiving canal, confirmed by GLU and CHOL minimum values. These parameters represent the main energy metabolites often used in estimation of fish health and condition and assessment of stressors in nature (Čož-Rakovac et al., 2005). Also, such energy reserves are required by fish to mediate the effects 
Table 5

Principal findings of the study over seasons/activity of the sugar plant, and three locations.

\begin{tabular}{|c|c|c|c|}
\hline & $\begin{array}{l}\text { Unaffected } \\
\text { stream }\end{array}$ & $\begin{array}{l}\text { Canal receiving the } \\
\text { effluent }\end{array}$ & $\begin{array}{l}\text { County canal further } \\
\text { downstream }\end{array}$ \\
\hline $\begin{array}{l}\text { Spring } \\
\text { (sugar cane } \\
\text { processing) }\end{array}$ & $\begin{array}{l}\text { - Highest } \\
\text { overall Fe } \\
\text { - Lowest } \\
\text { overall } \\
\text { monocytes } \\
\text { - Highest } \\
\text { overall } \\
\text { plasma } \\
\text { creatinine } \\
\text { and glu- } \\
\text { cose } \\
\text { - Gill alter- } \\
\text { ations: fu- } \\
\text { sion of } \\
\text { lamellae } \\
\text { pinnacles } \\
\text { (moderate) }\end{array}$ & $\begin{array}{l}\text { - Highest overall sus- } \\
\text { pended solids, BODn } \\
\text { - Highest overall } \mathrm{Pb} \text {, } \\
\mathrm{Cd}, \mathrm{Ni}, \mathrm{Zn}, \mathrm{Cu} \\
\text { - Highest overall } \\
\text { plasma albumins, total } \\
\text { proteins and triglyc- } \\
\text { erides } \\
\text { - Gill alterations: fusion } \\
\text { of lamellae, lamellar } \\
\text { bridging (severe) } \\
\text { - Spleen alterations: } \\
\text { melanomacrophage } \\
\text { centers (severe) }\end{array}$ & $\begin{array}{l}\text { - Highest overall } \mathrm{Cr} \\
\text { - Highest overall lym- } \\
\text { phocytes, monocytes, } \\
\text { haematocrit } \\
\text { - Highest overall } \\
\text { plasma SOD } \\
\text { - Highest overall } \\
\text { monogenean infesta- } \\
\text { tion alterations: } \\
\text { - Gill bridg- } \\
\text { lamellar curling and } \\
\text { inter-lamellar bridg } \\
\text { ing (severe) } \\
\text { - Spleen alterations: } \\
\text { granulomas, } \\
\text { melanomacrophage } \\
\text { centers (severe) }\end{array}$ \\
\hline $\begin{array}{l}\text { Summer } \\
\text { (sugar plant } \\
\text { inactive) }\end{array}$ & $\begin{array}{l}\text { - Gill alter- } \\
\text { ations: ir- } \\
\text { regularities } \\
\text { in lamellar } \\
\text { structure, } \\
\text { abundance } \\
\text { of mucous } \\
\text { cells } \\
\text { (mild) }\end{array}$ & $\begin{array}{l}\text { - Highest overall COD, } \\
\text { COD-Mn, total nitro- } \\
\text { gen, phosphate, total } \\
\text { phosphorus } \\
\text { - Highest overall } \\
\text { plasma urea, ALT; } \\
\text { lowest plasma SOD } \\
\text { - Gill alterations: disso- } \\
\text { ciations of secondary } \\
\text { lamellae, blood con- } \\
\text { gestions, damaged pil- } \\
\text { lar cells, abundance of } \\
\text { mucous cells (severe) } \\
\text { - Kidney alterations: } \\
\text { peritubular dilatations, } \\
\text { basophilic clusters, } \\
\text { macrophage infiltra- } \\
\text { tion of tubules (severe) } \\
\text { - Liver alterations: dis- } \\
\text { appearance of cell } \\
\text { walls, karyolysis and } \\
\text { binuclear hepatocytes } \\
\text { (severe) }\end{array}$ & $\begin{array}{l}\text { - Gill alterations: } \\
\text { shortened secondary } \\
\text { lamellae, atrophy, } \\
\text { necrosis (moderate) } \\
\text { - Kidney alterations: } \\
\text { multifocal granulo- } \\
\text { mas, tubular degener- } \\
\text { ations, diminished lu- } \\
\text { men (moderate) } \\
\text { - Liver alterations: he- } \\
\text { patocyte apoptosis, } \\
\text { nuclear changes } \\
\text { (moderate) }\end{array}$ \\
\hline
\end{tabular}

Table 5 (Continued)

\begin{tabular}{|c|c|c|c|}
\hline & $\begin{array}{l}\text { Unaffected } \\
\text { stream }\end{array}$ & $\begin{array}{l}\text { Canal receiving the } \\
\text { effluent }\end{array}$ & $\begin{array}{l}\text { County canal further } \\
\text { downstream }\end{array}$ \\
\hline $\begin{array}{l}\text { Fall (sugar } \\
\text { beet } \\
\text { processing) }\end{array}$ & $\begin{array}{l}\text { - Highest } \\
\text { overall wa- } \\
\text { ter temper- } \\
\text { ature } \\
\text { - Highest } \\
\text { overall to- } \\
\text { tal leuko- } \\
\text { cytes and } \\
\text { granulo- } \\
\text { cytes }\end{array}$ & $\begin{array}{l}\text { - Highest overall am- } \\
\text { monium, nitrite, ni- } \\
\text { trate concentration; } \\
\text { lowest overall dis- } \\
\text { solved } \mathrm{O}_{2} \\
\text { - Lowest overall total } \\
\text { leukocytes, lympho- } \\
\text { cytes and granulocytes } \\
\text { - Highest overall } \\
\text { plasma ALP; lowest } \\
\text { plasma TRIG } \\
\text { - Gill alterations: hyper- } \\
\text { trophy of epithelial } \\
\text { and interlamellar cells, } \\
\text { necrosis, lymphocytic } \\
\text { infiltration (severe) } \\
\text { - Kidney alterations: de- } \\
\text { veloping nephrons, re- } \\
\text { duced lumen, hyper- } \\
\text { plasia and hypertrophy } \\
\text { of tubules, cloudy } \\
\text { swelling of tubule } \\
\text { cells (severe) } \\
\text { - Liver alterations: dis- } \\
\text { tention of sinusoids } \\
\text { and blood congestion } \\
\text { (severe) }\end{array}$ & $\begin{array}{l}\text { - Lowest overall } \mathrm{O}_{2} \\
\text { saturation } \\
\text { - Highest overall } \\
\text { plasma cholesterol } \\
\text { - Gill alterations: hy- } \\
\text { perplastic and hyper- } \\
\text { trophied mucous cells } \\
\text { (severe) } \\
\text { - Kidney alterations: } \\
\text { epithelial necrosis, } \\
\text { cloudy swelling of } \\
\text { tubule cells, atrophy } \\
\text { and necrosis of } \\
\text { glomeruls (moderate) } \\
\text { - Liver alterations: in- } \\
\text { flammatory leuko- } \\
\text { cyte infiltration, } \\
\text { anisokaryosis and py- } \\
\text { knotic nuclei (moder- } \\
\text { ate) }\end{array}$ \\
\hline
\end{tabular}

of stress and serve as energy buffers (Topić Popović et al., 2012). Therefore, given the decline in these values, the immune suppression and the weakening of the innate, non adaptive immune defense system of carp in the effluent-receiving waters in fall is very likely (Javed and Usmani, 2015). However, since ALT and ALP activities were not elevated in the effluent-receiving canal, the deleterious effects might have been of transient nature, as semi-permeable plasma membranes prevented the leakage of enzymes from damaged (liver) tissues (Topić Popović et al., 2006).

In spring, a significant decrease in SOD was noted in the fish from the effluent-receiving canal. Since SOD is one of the main antioxidative enzymes serving to detoxify reactive oxygen species (ROS), a decrease in its activity changes the redox status of the cells, and can be attributed to the inhibition of the superoxide radical formation (Ural, 2013) implying the reduced ability to protect cells against superoxide radicals. The municipal wastewaters were shown to decrease SOD activity, reflecting the damage to the SOD protein due to ROS overproduction (Karadag et al., 2014). In this work SOD activity had a seasonal pattern since the SOD variables in the County canal tended to increase together in spring and in summer, while in summer SOD tended to decrease as the fall SOD increased and vice versa. The highest overall SOD values measured were in spring and summer in County canal fish downstream. In chronic experiments antioxidant enzyme activities are usually increased in aquatic organisms, and high SOD activity indicates that fish could protect itself against the toxic effect of superoxide anion radical (Huang et al., 2007). Indeed, upon exposure of zebrafish (Danio rerio) to phenol pollutants, the trend of SOD activity was at first elevated, while with the adaptation to the concentration over time it gradually restored 

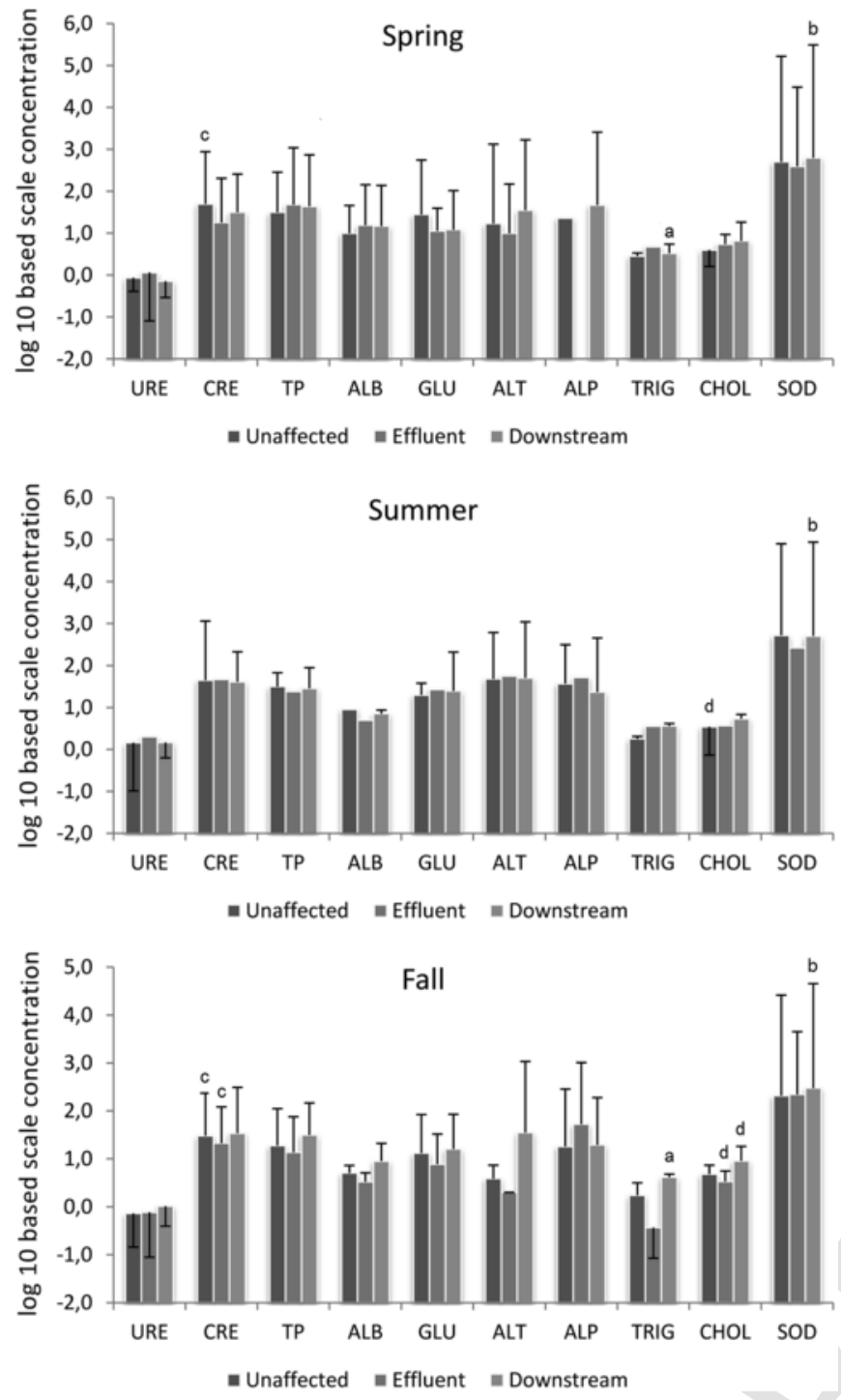

Fig. 5. Plasma biochemistry and oxidative stress parameters in Prussian carp over seasons. URE (urea), CRE (creatinine), TP (total proteins), ALB (albumin), GLU (glucose), ALT (alanine aminotransferase), ALP (alkaline phosphatase), TRIG (triglyceride), CHOL (cholesterol), and SOD (activity of superoxide dismutase) are presented. Concentration data are log-transformed (y-axis). The error bars represent the standard deviation. The differences between the parameters marked with identical lowercase lettering (a,b,c,d) are statistically significant $(p<0.05)$.

(Zhang et al., 2014). Also, it is not unlikely that organic contaminants may be measured at the most downstream sites from the WWTP (Jeffries et al., 2010), which indicates cumulative inputs of such compounds in the rivers, and surely impacts fish organismic indicators of tissue damage.

\subsection{Water quality and histopathology}

The complex matrix of the WWTP effluent under study varied seasonally and spatially, impacting the fish tissue responses, particularly evident from the gill structure. The severity of gill tissue alterations varied, and increased from spring till fall. Elevated ammonium levels in the effluent-receiving canal (spring $8.4 \mathrm{mg} / \mathrm{L}$, fall $20 \mathrm{mg} / \mathrm{L}$ ) might have reduced excretion and result in an uptake of ammonia into the tissues, not only gills, but also kidney and liver (Tetreault et al., 2012). Significant reduction in fish growth, irregular gill ventila-
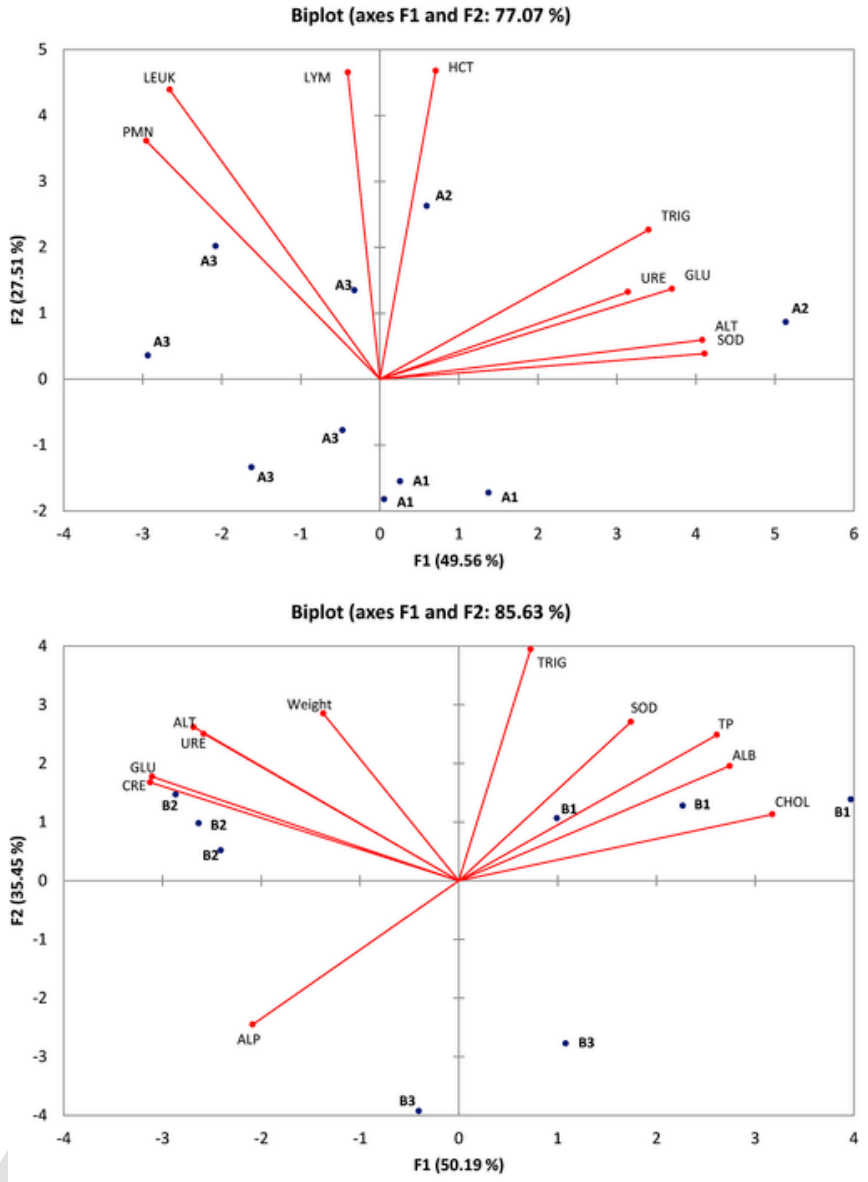

Biplot (axes F1 and F2: $82.34 \%$ )

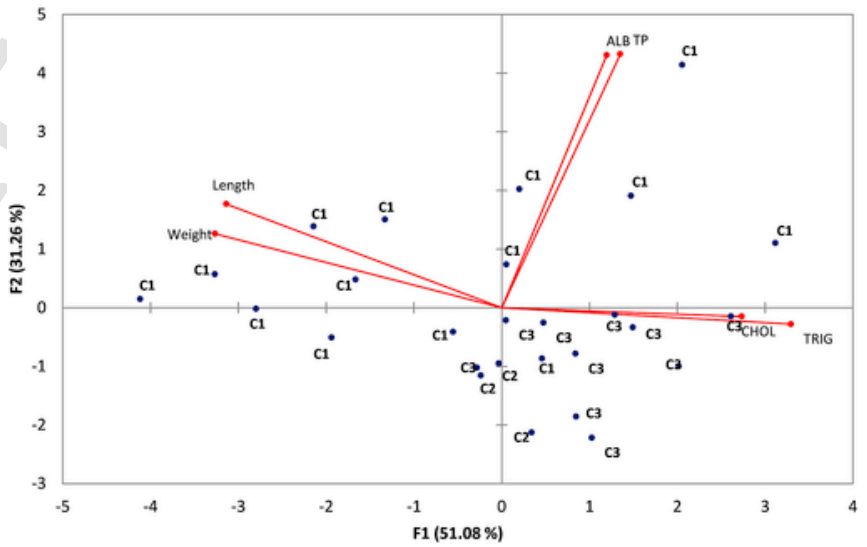

Fig. 6. Principal component analysis (PCA) for plasma biochemistry and oxidative stress parameters in Prussian carp from the unaffected stream (A), canal receiving the effluent (B) and County canal further downstream (C), over seasons (Spring: 1; Summer: 2, Fall: 3). Fish caught in spring in the unaffected stream (A1) grouped in the fourth quadrant, mostly on the mean values of URE, GLU, ALT, TRIG, SOD, and HCT which significantly differed from the mean values in other two seasons. Summer carp (A2) displayed ALT and SOD as dominant variables, while fall values (A3) grouped on the left side of the plot with significantly different means of PMN, LEUK and LYM. Effluent fish (B) grouped according to the season based on 11 parameters, 10 of which were responsible for grouping of spring and summer parameters, ALP significantly varying in fall (B3). PCA identified only 6 parameters as significant in County canal fish (C), with fish length and weight as significant in spring (C1), and TRIG and CHOL in fall (C3).

tion and morphology, hyperplasia of gill epithelium and lamellae have been shown in fish chronically exposed to environmentally rele- 


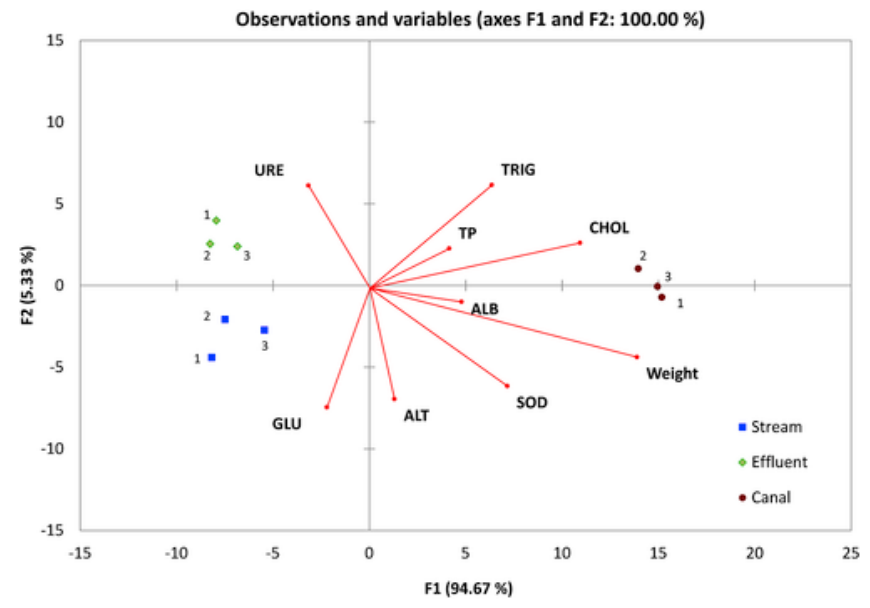

Fig. 7. Classification of Prussian carp based on mean values of biometry, haematology, plasma biochemistry and oxidative stress parameters according to the sampling sites and over seasons (spring: 1, summer: 2 , fall: 3 ), by use of Discriminant analysis (DA). Classification is showing $100 \%$ of the explained variance of significant cases, comprising of the first and second components. The first component in classification was dominant $(94.67 \%)$ with dominance variables of CHOL, SOD and weight of fish.

vant ammonium concentrations (Tetreault et al., 2012). In fish under this assay, gills of effluent fish in general exhibited slight to severe changes that included epithelial hyperplasia with lamellar fusion, epithelial hypertrophy, and proliferation of mucous cells. Such gill alterations were noted by others (Marioara et al., 2009; Parvathi and Sarsu, 2011; Nikalje et al., 2012) reporting them as typical gill lesions in response to a prolonged exposure to a wide range of heavy metals. Gills are a major target for metal toxicity and also the main point of entry for metals. Metals enter the apical and basolateral membranes of the specialized ion-transporting chloride cells in mostly divalent forms, such as $\mathrm{Co}^{+}, \mathrm{Zn}^{2+}, \mathrm{Cd}^{2+}$ (Olsson et al., 1998). As chloride cells are the primary site of calcium uptake, there is a competition between $\mathrm{Ca}$ and divalent metal ions for metal uptake. Thus increasing water hardness and acidified freshwaters reduce heavy metal toxicity (Ghosh and Adhikari, 2006). Exposure to toxicants, particularly heavy metals, leads to rapid inhibition of ion-translocating enzymes, such as $\mathrm{Na}^{+} / \mathrm{K}^{+}$-, and $\mathrm{Ca}^{2+}$-ATPase, as well as exchangers and ion channels (Di Giulio and Hinton, 2008). When the metal-biotic ligand complex, which encompasses sodium or calcium channel proteins, reaches a critical concentration, fish mortality occurs (Di Toro et al., 2001). Although the physiological mechanism of gill toxicity varies with various metals, biotic ligand models of acute metal toxicity may predict specific toxicity for individual species (Smith et al., 2015).

In the effluent fish in summer and fall (sugar beet processing), damages of gill structure included shortenings of secondary lamellae, atrophy and inflammatory processes with necrosis. Similar findings have been reported from environmental monitoring studies (Barišić et al., 2015). However, bridging of the neighboring secondary lamellae was one of the most pronounced changes in fish gills. Under acute exposure to heavy metals, bridging tends to reduce the total surface contact area between contaminated water flow and bloodstream (Topić Popović et al., 2015a). It is known that both soluble and suspended heavy metals are readily absorbed across fish gills causing deleterious changes in tissue structures, particularly $\mathrm{Cu}$ (Mustafa et al., 2012). In this study, $\mathrm{Cu}$ was extremely elevated $(270 \mu \mathrm{g} / \mathrm{L})$ in effluent-receiving canal in spring (sugar cane processing), and together with elevated suspended solids $(171 \mathrm{mg} / \mathrm{L})$ and other heavy metals (Cr $7.7 \mu \mathrm{g} / \mathrm{L}, \mathrm{Pb} 5.58 \mu \mathrm{g} / \mathrm{L}$, Ni $31 \mu \mathrm{g} / \mathrm{L}, \mathrm{Zn} 90 \mu \mathrm{g} / \mathrm{L}$ ), as well as hy- poxic conditions $(2.26 \mathrm{mg} \mathrm{O} / \mathrm{L})$ contributed to changes in gill morphology. The restricted lumen of the gill vessels forces red blood cells to move into reduced space, thus giving rise to further cellular deformations (Mustafa et al., 2012).

Liver is a target organ for lesions by pollutants due to its high metabolic activity in xenobiotic metabolism, excretion, digestion and storage (Bernet et al., 2000). The severity of the liver tissue damage in this study varied in relation to seasons and locations, as in the work of Kessabi et al. (2014), where it also varied in response to contaminants with bioaccumulation character which altered the liver function and led to gradual degeneration of cells. The detected dilations of sinusoids, found in livers of our effluent fish in fall, are presumed to be a consequence of long-term blood congestions and blockage of sinusoids, which widened to facilitate the flow of metabolites and detoxicants (Nikalje et al., 2012). Vacuolar structures in livers of those Prussian carp, filled with cellular debris, might be a response of detoxifying Kupffer cells to pollutants (Omar et al., 2013). Liver and gill lesions of fish from the effluent-receiving canal in spring could be linked with high plasma URE concentrations $(1.15 \pm 0.07 \mathrm{mmol} /$ L) of these fish, as well as high ammonium concentrations $(8.40 \mathrm{mg} /$ L), as in the work of Bernet et al. (2000) where polluted waters were associated with high blood urea concentration and liver and gill damage. The observed inflammatory clusters between hepatic lobules might indicate a reaction to bacterial stimuli, such as Aeromonas spp. isolated from water and liver tissues in our previous work (Topić Popović et al., 2015b). Liver changes in effluent and downstream fish in fall (sugar beet processing) in the form of distension of sinusoids, blood congestion, leukocyte infiltration, blood cells by hepatocytes, anisokaryosis and picnotic nuclei suggest high hepatocytes metabolic activity in response to the uptake of heavy metals (Omar et al., 2013). Also, vacuolar degeneration of spleen, found in the effluent fish, was assigned as an indicator of pollution with heavy metals (Georgieva et al., 2010). However, due to relatively normal ALT and ALP activities in fish from the effluent-receiving canal through all seasons, $(20.5 \pm 14.85 \mathrm{mmol} / \mathrm{L}, 23.21 \pm 24.45 \mathrm{mmol} / \mathrm{L}$ respectively, liver function was apparently preserved.

The signs of severe damage of the renal tissue and renal function due to heavy metal toxicity were reported from various fish species (Omar et al., 2013). Most prominent changes in this work, observed in effluent fish in summer (the highest overall Fe concentration, $720 \mu \mathrm{g}$ / L), were the increased number of basophilic clusters; while in fall (Fe $464 \mu \mathrm{g} / \mathrm{L}$ ) newly developed nephrons prevailed, along with epithelial necrosis and atrophy, eosinophilic granules and vacuoles in cytoplasm. According to Cormier et al. (1995) developing nephrons and basophilic clusters might serve as general indicators of ecological condition through nephrotoxicity at specific sites. Signs of necrosis and damage to kidney tubules, on the other hand, might be due to accumulation of inflammatory cells associated with metal toxicity (Tetreault et al., 2012). In spring, (sugar cane processing), when most of the measured heavy metals were significantly increased, elevated CRE levels of $26 \pm 11.31 \mathrm{mmol} / \mathrm{L}$ indicate impairment of kidney function, particularly glomerular insufficiency and disruption of carbohydrate metabolism (Omar et al., 2013). Kidney and gill tissue alterations might impair the ability of Prussian carp to survive and reproduce normally (Tetreault et al., 2012).

\section{Conclusions}

Although the avoidance response is one form of the phenotypic adaptation allowing fish to survive in the altered environment (Vosyliene et al., 2003), Prussian carp under investigation demonstrated a high capacity to live in waters of diminished quality with 
ability to compensate for environmental changes caused by treated wastewaters of municipal, hospital and industrial origin. The area of WWTP influence on Prussian carp biological responses, measured by the toxic effects on blood and tissue parameters, reaches far downstream and is not of a localized nature.

Prussian carp displayed responses and changes in physiological parameters with the most prominent effects on gill and liver cell damage and blood SOD activity, while CHOL and TRIG showed the strongest correlation with the season and sugar plant (beet processing) activity. Alterations of tissue morphology appear to be a consequence of loss of cellular and structural tissue integrity, as the degree of structural heterogeneity of fish organs was enhanced with increasing concentrations of heavy metals in the environment. These changes can be correlated with the oxidative stress levels and neutrofilia. Integrated histopathological, haematological and biochemical findings, however non specific to one particular agent, could thus serve as valuable biomarkers for native fish adaptive patterns and monitoring of water quality and pollution of freshwater ecosystems. The application of multivariate tools allowed discrimination of the most relevant predictors which outline unified fish biological responses to the effluent relative to location and seasons. It was also found valuable in other studies in monitoring the impact of complex mixtures of toxicants in aquatic ecosystems on fish species, and controlling conditions needed in validating and monitoring of fish health (Hashem Sweidan et al., 2015; Dzul-Caamal et al., 2016).

In aquatic environments impacted with complex contaminants acting synergistically, causal relationships between biological responses and environmental stressors should be interpreted. Thus, a set of risk analysis and risk management measures is recommendable for the area under study, particularly in the form of hazard identification, effect assessment, exposure assessment, characterization of risk and regulatory measures. They are of particular importance since deleterious effects of multiple stressors on (fish) populations are challenging to detect in native populations, which tend to be under constant or recurring exposure causing a prolonged physiological response. To that end, the research of early-warning signals (biomarkers), reflecting the adverse biochemical or cellular responses towards anthropogenic pollution, measurable in body fluids, cells or tissues (van der Ost et al., 2003), is aimed to indicate the effects at higher biological levels. Integrated histopathological, haematological and biochemical analyses, as biomarkers of effect, yielded information on biological effects of mixture of pollutants in "real world exposure", and helped in assessment of the magnitude of impact of treated wastewater on native fish. We therefore recommend the use of coupled biomarkers as a tool for improving ecological risk assessment and biomonitoring of environmental pollution.

\section{Conflict of interest}

The authors declare no conflict of interest.

\section{Acknowledgements}

This work was supported by the Croatian MSES Grant No. 098-1782739-249, and carried out in accordance with the EC Directive 86/609/EEC for animal experiments.

\section{References}

Adams, M.S., 2002. Biological indicators of aquatic ecosystem stress: introduction and overview. In: Adams, M.S. (Ed.), Biological Indicators of Aquatic Ecosystem Stress. American Fisheries Society, Bethesda, MD, pp. 1-13.

Adams, M.S., Greeley, M.S., 1999. Establishing possible links between aquatic ecosystem health and human health: an integrated approach. In: Di Giulo, R.T.,
Monosson, E. (Eds.), Interconnections between Human and Ecosystem Health. Chapman and Hall, London, pp. 91-102.

Ainsworth, A.K., Dexiang, C., Waterstrat, P.R., 1991. Changes in peripheral blood leukocyte percentages and function of neutrophils in stressed channel catfish. J. Aquat. Anim. Health 3, 41-47.

Aksentijević, K.T., 2010. Influence of Stress on the Qualitative and Quantitative Ratio of Polymorphonuclears in Blood of Prussian Carp (Carassius gibelio, Bloch, 1782). 71. M.sc. thesis, CIARD RING Registry.

Al-Alkel, A.S., Shamsi, M.J.K., 1996. Hexavalent chromium: toxicity and impact on carbohydrate metabolism and haematological parameters of carp (Cyprinus carpio L.) from Saudi Arabia. Aquat. Sci. 58 (1), 24-30.

Alvarez-Pellitero, P., 2008. Fish immunity and parasite infections: from innate immunity to immunoprophylactic prospects. Vet. Immunol. Immunopathol. 126 (3), 171-198.

Arkoosh, M.R., Casillas, E., Clemons, E., Kagley, A.N., Olson, R., Reno, P., Stein, J.E., 1998. Effect of pollution on fish diseases: potential impacts on salmonid populations. J. Aquat. Anim. Health 10 (2), 182-190.

Barber, L.B., Brown, G.K., Nettesheim, T.G., Murphy, E.W., Bartell, S.E., Schoenfuss, H.L., 2011. Effects of biologically-active chemical mixtures on fish in a wastewater-impacted urban stream. Sci. Total Environ. 409, 4720-4728.

Barišić, J., Dragun, Z., Ramani, S., Filipović Marijić, V., Krasnići, N., Čož-Rakovac, R., Kostov, V., Rebok, K., Jordanova, M., 2015. Evaluation of histopathological alterations in the gills of Vardar chub (Squalius vardarensis Karaman) as an indicator of river pollution. Ecotoxicol. Environ. Saf. 118, 158-166.

Bayoumy, E.M., Osman, H.A.M., El-Bana, Laya F., Hassanain, M.A., 2008. Monogenean parasites as bioindicators for heavy metals status in some Egyptian Red Sea fishes. Glob. Vet. 2 (3), 117-122.

Bernet, D., Schmidt-Posthaus, H., Wahli, T., Burkhardt-Holm, P., 2000. Effects of wastewater on fish health an integrated approach to biomarker responses in brown trout (Salmo trutta L.). J. Aquat. Ecosyst. Stress Recovery 8, 143-151.

Bernet, D., Schmidt, H., Wahli, T., Burkhardt-Holm, P., 2001. Effluent from a sewage treatment works causes changes in serum chemistry of brown trout (Salmo trutta L.). Ecotoxicol. Environ. Saf. 48, 140-147.

Billard, S.M., Khan, R.A., 2003. Chronic stress in cunner, Tautogolabrus adspersus, exposed to municipal and industrial effluents. Ecotoxicol. Environ. Saf. 55 (1), 9-18.

Bosque-Sendra, J.M., Cuadros-Rodríguez, L., Ruiz-Samblás, C., de la Mata, A.P., 2012. Combining chromatography and chemometrics for the characterization and authentication of fats and oils from triacylglycerol compositional data - a review. Anal. Chim. Acta 724, 1-11.

Charlton-Menys, V., Liu, Y., Durrington, P.N., 2006. Semiautomated method for determination of serum paraoxonase activity using paraoxon as substrate. Clin. Chem. 52, 453-457.

Chen, C.Y., Wooster, G.A., Getchell, R.G., Bowser, P.R., Timmons, M.B., 2003. Blood chemistry of healthy, nephrocalcinosis-affected and ozone-treated tilapia in a recirculation system, with application of discriminant analysis. Aquaculture 218, 89-102.

Cheesman, O.D., 2004. Environmental Impacts of Sugar Production the Cultivation and Processing of Sugarcane and Sugar Beet. CABI Publishing, Cromwell Press, Trowbridge.

Clauss, T.M., Dove, A.D., Arnold, J.E., 2008. Hematologic disorders of fish. Vet. Clin. North Am. Exot. Anim. Pract. 11 (3), 445-462.

Cormier, S.M., Neiheisel, T.W., Wernsing, P., Racine, R.N., Reimschuessel, R., 1995. New nephron development in fish from polluted waters: a possible biomarker. Ecotoxicology 4 (3), 157-168.

Čož-Rakovac, R., Strunjak-Perović, I., Hacmanjek, M., Topić Popović, N., Lipej, Z., Šoštarić, B., 2005. Blood chemistry and histological properties of wild and cultured sea bass (Dicentrarchus labrax) in the North Adriatic Sea. Vet. Res. Commun. 29, 677-687.

Densen, P., Mandell, G.L., 1990. Granulocytic phagocytes. In: Mandell, G.L., Douglas, R.G., Bennet, J.E. (Eds.), Principles and Practices of Infectious Diseases. Churchill Livingstone, New York, pp. 81-101.

Di Giulio, R.T., Hinton, D.E. (Eds.), 2008. The Toxicology of Fishes. CRC Press, Taylor and Francis Group, Boca Raton, p. 1096.

Di Toro, D.M., Allen, H.E., Bergman, H.L., Meyer, J.S., Paquin, P.R., Santore, R.C., 2001. Biotic ligand model of the acute toxicity of metals. Technical basis. Environ. Toxicol. Chem. 20 (10), 2383-2396.

Dove, A.D.M., Arnold, J.E., 2008. Hematologic disorders of fish. Vet. Clin. Exot. Anim. 11, 445-462.

Dunier, M., 1996. Water pollution and immunosuppression of freshwater fish. Ital. J. Zool. 63 (4), 303-309.

Dzul-Caamal, R., Olivares-Rubio, H.F., Salazar-Coria, L., Rocha-Gómez, M.A., Vega-López, A., 2016. Multivariate analysis of biochemical responses using non-invasive methods to evaluate the health status of the endangered blackfin goodeid (Girardinichthys viviparus). Ecol. Indic. 60, 1118-1129.

El-Shafai, S.A., Gijzen, H.J., Nasr, F.A., El-Gohary, F.A., 2004. Microbial quality of tilapia reared in fecal-contaminated ponds. Environ. Res. 95, 231-238 
Farahi, A., Kasiri, M., Talebi, A., Sudagar, M., 2011. Effects of clove extract as an anesthetic on sperm motility traits and some hematological parameters in Prussian carp Carassius gibelio. Adv. Environ. Biol. 1406-1411.

Flores-Lopes, F., Thomaz, A.T., 2011. Histopathologic alterations observed in fish gills as a tool in environmental monitoring. Braz. J. Biol. 71 (1), 1-11.

Fudge, A.M., 2000. Laboratory Medicine for Avian and Exotic Pets. WB Saunders, Philadelphia.

Garmendia, L., Izagirre, U., Soto, M., Lermen, L., Koschorreck, J., 2015. Combining chemical and biological endpoints, a major challenge for twenty-first century's environmental specimen banks. Environ. Sci. Pollut. Res. 22, 1631-1634.

Georgieva, E., Arnaudov, A., Velcheva, I., 2010. Clinical, hematological and morphological studies on ex situ induced copper intoxication in Crucian carp (Carassius gibelio). J. Cent. Eur. Agric. 11 (2), 165-172.

Gluth, G., Hanke, W., 1985. A comparison of physiological changes in carp, Cyprinus carpio, induced by several pollutants at sublethal concentrations. I. The dependency on exposure time. Ecotoxicol. Environ. Saf. 9 (2), 179-188.

Groff, J.M., Zinkl, J.G., 1999. Hematology and clinical chemistry of cyprinid fish. Vet. Clin. North Am. Exot. Anim. Pract. 2 (3), 741-746.

Ghosh, L., Adhikari, S., 2006. Accumulation of heavy metals in freshwater fish-An assessment of toxic interactions with calcium. Am. J. Food Techol. 1 (2), 139-148.

Hale, R., Coleman, R., Pettigrove, V., Swearer, S.E., 2015. Identifying, preventing and mitigating ecological traps to improve to management of urban aquatic ecosystems. J. Appl. Ecol. 52 (4), 928-939.

Hashem Sweidan, A., El-Bendary, N., Hegazy, O.M., Hassanien, A.E., Snasel, V., 2015. Water pollution detection system based on fish gills as a biomarker. Proced Comput. Sci. 65, 601-611.

Heath, A.G., 1995. Water Pollution and Fish Physiology. CRC Press Inc, Boca Raton, Florida.

Hrubec, T.C., Smith, S.A., 2000. Hematology of fish. In: Feldman, B.F., Zinkl, J.G., Jain, N.C. (Eds.), Veterinary Hematology. Lippincott Williams \& Wilkins, Philadelphia, pp. 1120-1125.

Huang, D.J., Zhang, Y.M., Song, G., Long, J., Liu, J.H., Ji, W.H., 2007. Contaminants-induced oxidative damage on the carp Cyprinus carpio collected from the Upper Yellow River, China. Environ. Monit. Assess. 128, 483-488.

Jameson, S.C., Erdmann, M.V., Karr, J.R., Potts, K.W., 2001. Charting a course toward diagnostic monitoring: a continuing review of coral reef attributes and a research strategy for creating coral reef indexes of biotic integrity. Bull. Mar. Sci. 69 (2), 701-744.

Jawad, L.A., Al-Mukhtar, M.A., Ahmed, H.K., 2004. The relationship between haematocrit and some biological parameters of the Indian shad, Tenualosa ilisha (Family Clupeidae). Anim. Biodivers. Conserv. 27 (2), 47-52.

Javed, M., Usmani, N., 2015. Stress response of biomolecules (carbohydrate, protein and lipid profiles) in fish Channa punctatus inhabiting river polluted by thermal power plant effluent. Saudi J. Biol. Sci. 22, 237-242.

Javed, M., Usmani, N., 2015a. Impact of heavy metal toxicity on hematology and glycogen status of fish: a review. Proc. Natl. Acad. Sci. India Sect. B Biol. Sci. 85 (4), 889-900.

Jeffries, K.M., Jackson, L.J., Ikonomou, M.G., Habibi, H.R., 2010. Presence of natural and anthropogenic organic contaminants and potential fish health impacts along two river gradients in Alberta, Canada. Environ. Toxicol. Chem. 29 (10), 2379-2387.

Karadag, H., Firat, O., Firat, O., 2014. Use of oxidative stress biomarkers in Cyprinus carpio L. for the evaluation of water pollution in Ataturk Dam Lake (Adiyaman, Turkey). Bull. Environ. Contam. Toxicol. 92, 289-293.

Kaur, R., Dua, A., 2014. Adverse effects on histology of liver and kidney in fish Channa punctatus exposed to wastewater from Tung Dhab drain in Amritsar, India. J. Environ. Biol. 35, 265-272.

Kelly, J.M., Janz, D.M., 2008. Altered energetics and parasitism in juvenile northern pike (Esox lucius) inhabiting metal-mining contaminated lake. Ecotoxicol. Environ. Saf. 70 (3), 357-369.

Kessabi, K., Hwas, Z., Sassi, A., Said, K., Messaoudi, I., 2014. Heavy metal accumulation and histomorphological alterations in Aphanius fasciatus (Pisces, Cyprinodontidae) from the Gulf of Gabes (Tunisia). Environ. Sci. Pollut. Res. 21 (24), 14099-14109.

Kroupova, H., Machova, J., Svobodova, Z., 2005. Nitrite influence on fish: a review. Vet. Med. Czech 50 (11), 461-471.

Larrick, S.R., Dickson, K.L., Cherry, D.S., Cairns Jr., J., 1978. Determining fish avoidance of polluted water. Hydrobiologia 61 (3), 257-265.

Lusk, M.R., Luskova, V., Hanel, L., 2010. Alien fish species in the Czech Republic and their impact on the native fish fauna. Folia Zool. 59, 57-72.

Marioara, N., Dumitrescu, G., Petculescu-Ciochină, L., Bănăţean-Dunea, I., Moţ, M., Tăpălagă, I., Lunca, M., Boca, L., 2009. Pathological tissue lesions induced by chronic cadmium intoxication in silver Crucian carp Carassius auratus gibelio. SPASB 42 (2), 84-90.

Mustafa, S.A., Davies, S.J., Jha, A.N., 2012. Determination of hypoxia and dietary copper mediated sub-lethal toxicity in carp, Cyprinus carpio, at different levels of biological organization. Chemosphere 87, 413-422.
Nikalje, S.B., Muley, D.V., Angadi, S.M., 2012. Histopathological changes in liver of freshwater major carp, Labeo rohita after acute and chronic exposure to textile mill effluent. The Bioscan 7 (2), 215-220.

Olsson, P.A., Kling, P., Hogstrand, C., 1998. Mechanisms of heavy metal accumulation and toxicity in fish. In: Langston, W.J., et al. (Eds.), Metal Metabolism in Aquatic Environments. Springer Science + Business Media Dordrecht.

Omar, W.A., Zaghloul, K.H., Abdel-Khalek, A.A., Abo-Hegab, S., 2013. Risk assessment and toxic effects of metal pollution in two cultured and wild fish species from highly degraded aquatic habitats. Arch. Environ. Contam. Toxicol. $65,753-764$.

Overstreet, R.M., 1993. Parasitic diseases of fishes and their relationship with toxicants and other environmental factors. In: Couch, J.A., Fournie, J.W. (Eds.), Pathobiology of Marine and Estuarine Organisms. CRC Press, pp. 111-156.

Owen, R., Galloway, T.S., Hagger, J.A., Jones, M.B., Depledge, M.H., 2008. Biomarkers and environmental risk assessment Guiding principles from the human health field. Mar. Pollut. Bull. 56, 613-619.

Palić, D., Beck, L.S., Palić, J., Andreasen, C.B., 2011. Use of rapid cytochemical staining to characterize fish blood leukocytes in species of special concern and determine potential for neutrophil functional testing. Fish. Shellfish Immunol. 30, 646-652.

Parvathi, K.S., Sarsu, C., 2011. Effect of chromium on histological alteration of gill, liver and kidney of freshwater teleost, Cyprinus carpio. Int. J. Fish. Aquac. 6 (1), $1-5$.

Radić, S., Gregorović, G., Stipaničev, D., Cvjetko, P., Šrut, M., Vujčić, V., Oreščanin, V., Klobučar, G.I.V., 2013. Assessment of surface water in the vicinity of fertilizer factory using fish and plants. Ecotoxicol. Environ. Saf. 96, 32-40.

Rakauskas, V., Blaevièius, E., 2010. An assessment of parasite variation in wild populations of roach, Rutilus rutilus (L.), in Lithuanian Sungais. Arch. Pol. Fish. 18, 213-223.

Roberts, D.J., 2001. Fish Pathology. WB Saunders, Edinburgh, 472.

Sahu, O.P., Chaudhari, P.K., 2015. The characteristics, effects, and treatment of wastewater in sugarcane industry. Water Qual. Expo. Health 7, 435-444.

Schjolden, J., Sørensen, J., Nilsson, G.E., Poléo, A.B.S., 2007. The toxicity of copper to crucian carp (Carassius carassius) in soft water. Sci. Total Environ. 384 (1-3), 239-251.

Siddal, R., Koskivaara, M., Valtonen, E.T., 1997. Dactylogyrus (Monogenea) infections on the gills of roach (Rutilus rutilus L) experimentally exposed to pulp and paper mill effluent. Parasitology 114, 439-446.

Smith, K.S., Balistrieri, L.S., Todd, A.S., 2015. Using biotic ligand models to predict metal toxicity in mineralized systems. Appl. Geochem. 57, 55-72.

Sniezsko, S.F., 1974. The effects of environmental stress on outbreaks of infectious diseases of fishes. J. Fish. Biol. 6, 197-208.

Snyder, E.M., Snyder, S.A., Kelly, K.L., Gross, T.S., Villeneuve, D.L., Fitzgerald, S.D., Villalobos, S.A., Giesy, J.P., 2004. Reproductive responses of common carp (Cyprinus carpio) exposed in cages to influent of the Las Vegas wash in Lake Mead, Nevada, from late winter to early spring. Environ. Sci. Technol. 38, 6385-6395.

Stoskopf, M.K., 1993. Clinical pathology of carp, goldfish, and koi. In: Stoskopf, W.B. (Ed.), Fish Medicine. MK Saunders Company, Philapelphia, USA, pp. 450-453.

Svetina, A., Matašin, Z., Tofant, A., Vučemilo, M., Fijan, N., 2002. Haematology and some blood chemical parameters of young carp till the age of three years. Acta Vet. Hung. 50 (4), 459-467.

Tetreault, G.R., Bennett, C.J., Cheng, C., Servos, M.R., McMaster, M.E., 2012. Reproductive and histopathological effects in wild fish inhabiting an effluent-dominated stream, Wascana Creek, SK, Canada. Aquat. Toxicol. 110-111, 149-161.

Topić Popović, N., Strunjak-Perović, I., Čož-Rakovac, R., Hacmanjek, M., 2006. Plasma metabolites and enzymes of bluefin tuna Thunnus thynnus and liver histology. Period Biol. 108 (2), 127-131.

Topić Popović, N., Kozačinski, L., Strunjak-Perović, I., Čož-Rakovac, R., Jadan, M., Cvrtila-Fleck, , Barišić, J., 2012. Fatty acid and proximate composition of bluefin tuna (Thunnus thynnus) muscle with regard to plasma lipids. Aquac. Res. 43, 722-729.

Topić Popović, N., Strunjak-Perović, I., Sauerborn Klobučar, R., Barišić, J., Babić, S., Jadan, M., Kepec, S., Kazazić, S., Matijatko, V., Beer Ljubić, B., Car, I., Repec, S., Stipaničev, D., Klobučar, G., Čož-Rakovac, R., 2015a. Impact of treated wastewater on organismic biosensors at various levels of biological organization. Sci. Total Environ. 538, 23-37.

Topić Popović, N., Kazazić, S., Strunjak-Perović, I., Barišić, J., Sauerborn Klobučar, R., Kepec, S., Čož-Rakovac, R., 2015b. Detection and diversity of aeromonads from treated wastewater and fish inhabiting effluent and downstream waters. Ecotoxicol. Environ. Saf. 120, 235-242.

Ural, M.S., 2013. Chlorpyrifos-induced changes in oxidant/antioxidant status and haematological parameters of Cyprinus carpio carpio: ameliorative effect of lycopene. Chemosphere 90, 2059-2064.

USFWS, 2012. Prussian Carp (Carassius gibelio) Ecological Risk Screening Summary. Web Version - 8/14/2012 U.S. Fish and Wildlife Service. www.fws.gov/ 
injuriouswildlife/pdf_files/Carassius_gibelio_WEB_8-14-2012.pdf. Accessed 27 April 2015.

van der Ost, R., Beyer, J., Vermeulen, N.P.E., 2003. Fish bioaccumulation and biomarkers in environmental risk assessment: a review. Environ. Toxicol. Pharmacol. 13, 57-149.

Vosyliene, M.Z., Kazlauskiene, N., Svecevičius, G., 2003. Effect of a heavy metal model mixture on biological parameters of rainbow trout Oncorhynchus mykiss. Environ. Sci. Pollut. R. 10 (2), 103-107.

Wedemeyer, G.A., Yasutake, W.T., 1977. Clinical Methods for the Assessment of the Effects of Environmental Stress on Fish Health. (Technical Papers of the U.S. Fish and Wildlife Service, Washington, DC).

Wells, R.M.G., Pankhurst, N.W., 1999. Evaluation of simple instruments for the measurement of blood glucose and lactate, and plasma protein as stress indicators in fish. J. World Aquac. Soc. 30 (2), 276-284.
Witeska, M., 2005. Stress in fish - hematological and immunological effects of heavy metals. J. Ichthyol. 1, 35-41.

Zelikoff, J.T., 1993. Metal pollution-induced immunomodulation in fish. Annu. Rev. Fish. Dis. 3, 305-325.

Zelikoff, J.T., Raymond, A., Carlson, E., Li, Y., Beaman, J.R., Anderson, M., 2000. Biomarkers of immunotoxicity in fish: from the lab to the ocean. Toxicol. Lett. 112/113, 325-331.

Zhang, Q., Wu, J., Chen, S., Feng, Y., 2014. Influences of organic pollutants in water on antioxidant enzyme in zebrafish. J. Chem. Pharm. Res. 6 (4), 1014-1021. 